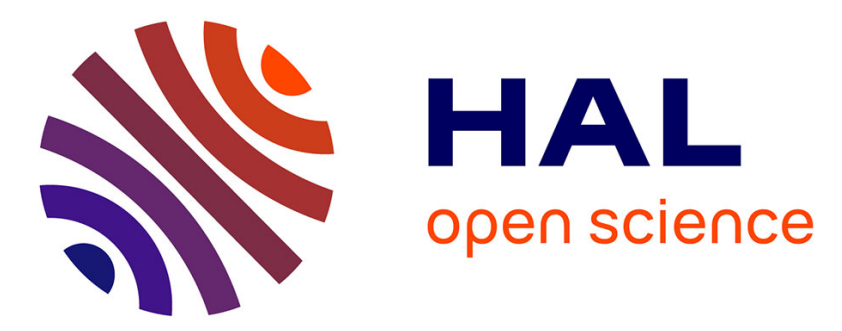

\title{
Phylogeography and pigment type diversity of Synechococcus cyanobacteria in surface waters of the northwestern Pacific Ocean
}

Xiaomin Xia, Frédéric Partensky, Laurence Garczarek, Koji Suzuki, Cui Guo, Shun Yan Cheung, Hongbin Liu

\section{To cite this version:}

Xiaomin Xia, Frédéric Partensky, Laurence Garczarek, Koji Suzuki, Cui Guo, et al.. Phylogeography and pigment type diversity of Synechococcus cyanobacteria in surface waters of the northwestern Pacific Ocean. Environmental Microbiology, 2016, 19 (1), pp.142-158 10.1111/1462-2920.13541 . hal01377154

\section{HAL Id: hal-01377154 https://hal.sorbonne-universite.fr/hal-01377154}

Submitted on 6 Oct 2016

HAL is a multi-disciplinary open access archive for the deposit and dissemination of scientific research documents, whether they are published or not. The documents may come from teaching and research institutions in France or abroad, or from public or private research centers.
L'archive ouverte pluridisciplinaire HAL, est destinée au dépôt et à la diffusion de documents scientifiques de niveau recherche, publiés ou non, émanant des établissements d'enseignement et de recherche français ou étrangers, des laboratoires publics ou privés. 


\section{Phylogeography and pigment type diversity of Synechococcus}

cyanobacteria in surface waters of the northwestern Pacific

(1)

\section{Ocean}

Xiaomin Xia ${ }^{1}$, Frédéric Partensky², Laurence Garczarek ${ }^{2}$, Koji Suzuki $^{3}$, Cui Guo ${ }^{1}$, Shun Yan Cheung ${ }^{1}$, Hongbin Liu $^{1 *}$

1. Division of Life Science, The Hong Kong University of Science and Technology, Hong Kong

2. Sorbonne Universités, Université Paris 6, CNRS UMR 7144, Marine Plankton Group, MaPP team, CS 90074, Station Biologique, 29688 Roscoff Cedex, France

3. Faculty of Environmental Earth Science, Hokkaido University/JST- CREST, Japan

Running Title: Synechococcus community diversity in the northwestern Pacific Ocean

*Corresponding author: E-mail liuhb@ust.hk; Tel. (+852) 23587341; Fax (+852) 23581559. 


\section{Summary}

The widespread unicellular cyanobacteria Synechococcus are major contributors to global marine primary production. Here we report their abundance, phylogenetic diversity (as assessed using the RNA polymerase gamma subunit gene rpoC1) and pigment diversity (as indirectly assessed using the laterally transferred cpeBA genes, encoding phycoerythrin-I) in surface waters of the northwestern Pacific Ocean, sampled over nine distinct cruises (20082015). Abundance of Synechococcus was low in the subarctic ocean and South China Sea, intermediate in the western subtropical Pacific Ocean, and the highest in the Japan and East China seas. Clades I and II were by far the most abundant Synechococcus lineages, the former dominating in temperate cold waters and the latter in (sub)tropical waters. Clades III and VI were also fairly abundant in warm waters, but with a narrower distribution than clade II. One type of chromatic acclimater (3dA) largely dominated the Synechococcus communities in the subarctic ocean, while another $(3 \mathrm{~dB})$ and/or cells with a fixed high phycourobilin to phycoerythrobilin ratio (pigment type 3c) predominated at mid and low latitudes. Altogether, our results suggest that the variety of pigment content found in most Synechococcus clades considerably extends the niches that they can colonize and therefore the whole genus habitat.

44 Key words: cyanobacteria, Synechococcus, rpoC1, western Pacific Ocean, marginal sea, pigment type, genetic diversity. 
49 Abbreviations: phycocyanobilin (PCB); phycoerrythrobilin (PEB); phycourobilin (PUB);

50 type IV chromatic acclimaters (CA4); photosynthetically available radiation (PAR); the limit

51 of detection (LOD); 16S-23S internal transcribed spacer region (ITS); the operational

52 taxonomic unit (OTU); Non-metric multidimensional scaling analysis (NMDS); $\underline{\text { redundancy }}$

53 analysis (RDA).

54 


\section{Introduction}

Marine unicellular cyanobacteria belonging to the Synechococcus genus are ubiquitously distributed in the euphotic layer of the ocean and play a key role in the marine ecosystems in terms of global carbon biomass (Garcia-Pichel et al., 2003; Buitenhuis et al., 2012) and net primary production (Liu et al., 1998; Flombaum et al., 2013). Synechococcus communities are both phenotypically and phylogenetically diverse. Synechococcus cells harvest light using large complexes called phycobilisomes, constituted by a core of allophycocyanin surrounded by six radiating rods with highly variable phycobiliprotein and chromophore composition (Six et al., 2007). Based on the different phycobiliprotein composition of phycobilisome rods, Synechococcus strains can be divided into three main pigment types: type 1 containing only phycocyanin (PC), type 2 containing both PC and phycoerythrin-I (PEI) and type 3 possessing PC, PEI and phycoerythrin-II (PEII). PEI and PEII have different amino acid sequence and bilin composition and content, with the latter always binding both phycoerythrobilin (PEB) and phycourobilin (PUB), whereas the former either bind only PEB or both PEB and PUB (Ong and Glazer, 1991; Six et al., 2007). In terms of chromophorylation, phycobilisomes of pigment type 1 bind only phycocyanobilin (PCB), type 2 bind both PCB and PEB, while type 3 bind PCB, PEB and PUB. Pigment type 3 Synechococcus can be further divided into type 3a (PUB/PEB $<0.6), 3 b(0.6 \leq \mathrm{PUB} / \mathrm{PEB}<1.6), 3 \mathrm{c}(\mathrm{PUB} / \mathrm{PEB} \geq 1.6)$ and type $3 \mathrm{~d} / \mathrm{e}$ (variable PUB/PEB), according to the in vivo PUB/PEB ratio of whole cells, as assessed using the ratio of the fluorescence excitation peaks of these two chromophores, i.e. usually $E_{495} \mathrm{~nm}: \mathrm{Ex}_{550 \mathrm{~nm}}$ (Everroad et al., 2006; Six et al., 2007, Everroad and Wood, 2012; Humily et al., 2013). Strains displaying either high (type 3d) or low (type 3e) amplitude of variation of their PUB/PEB ratio 
in response to change in light quality from blue to green light (and vice versa) are also called

type IV chromatic acclimaters (CA4). Genes involved in the CA4 process are gathered into a small genomic island with two possible configurations, CA4-A and CA4-B (Humily et al., 2013). The chromatically acclimating strains that possess a CA4-A or a CA4-B island type are called $3 \mathrm{dA}$ or $3 \mathrm{~dB}$, respectively, but it is noteworthy that a number of strains that possess such an island do not actually chromatically acclimate and therefore display a fixed PUB/PEB ratio, possibly due to a dysfunction of the CA4 regulatory machinery.

The distribution of pigment types has been studied in the marine environment using various approaches, including epifluorescence microscopy (Wang et al., 2011), flow cytometry (Olson et al., 1988), spectrofluorimetry (Lantoine and Neveux, 1997; Wood et al., 1998) and sequencing of clone libraries of $c p c B A$ and $c p e B A$ operons, encoding alpha and beta subunits of PC and PEI, respectively (Liu et al., 2014; Chung et al., 2015). Indeed, in sharp contrast with phylogenies obtained from housekeeping genes such as $16 \mathrm{~S}$ rRNA or rpoCl genes, phylogenies made using such phycobiliprotein-encoding genes reflect better pigment content than vertical phylogeny (Six et al., 2007; Everroad et al., 2012; Humily et al., 2014). While the characterization of cultured Synechococcus isolates showed that different pigment types can collect different wavelengths of light (Olson et al., 1988; Olson et al., 1990; Stomp et al., 2004; Six et al.,2007), field studies suggest that these differences can allow them to colonize distinct light quality niches of the marine environment (Wood, 1985; Wood et al., 1999; Stomp et al., 2007; Liu et al., 2014). Pigment type 1 Synechococcus harvest optimally red-orange light and dominate in turbid estuarine waters (Wang et al., 2011; Liu et al., 2014), whereas type 2 mainly absorb yellow-green light and preferentially thrive in turbid coastal or continental shelf waters 
99

100

101

102

103

104

105

106

107

108

109

110

111

112

113

114

115

116

117

(Wood et al., 1998). The different pigment subtypes within type 3 would mainly occur in mesotrophic or oligotrophic oceanic waters where green or blue light predominate, respectively (Olson et al., 1988; Wood et al., 1998). Both cultivation-dependent and independent methods used to study the pigment diversity of Synechococcus communities have shown that multiple pigment types co-occur in marine surface waters (Choi and Noh, 2009; Haverkamp et al., 2009; Humily et al., 2014; Larsson et al., 2014).

The vertical phylogeny of the marine Synechococcus group has also been extensively studied. Based on the 16S rRNA gene marker, marine Synechococcus have been classified into three phylogenetic subclusters, 5.1, 5.2 and 5.3 (hereafter S5.1, S5.2 and S5.3; Dufresne et al., 2008). S5.1, which is more diverse than the other two subclusters, contains at least sixteen clades (Ahlgren and Rocap, 2012). S5.1 and S5.3 are mainly composed of pigment types 2 and 3, except the euryhaline clade VIII (within S5.1), which so far only comprises strains belonging to pigment type 1. In contrast, S5.2 contains pigment types 1 and 2 (e.g., strains CB0101 and CB0205; Chen et al., 2006). Studies of the global distribution of Synechococcus community composition have revealed a clear spatial partitioning for the main Synechococcus lineages (Zwirglmaier et al., 2008; Huang et al., 2012; Mazard et al., 2012; Sohm et al., 2015; Farrant et al., 2016). Indeed, in agreement with the different thermal growth range and preference of representative strains (Pittera et al., 2014), clade II was found to be prevalent in warm subtropical and tropical waters, while clades I and IV dominate in cold waters. The relative abundance of Synechococcus lineages also undergo seasonal variations (Fuller et al., 2003; Post et al., 2011; Chung et al., 2015). For instance, clade III often occurs in summer in warm, stratified surface waters, whereas clade XII are generally prevalent in fall and winter (Post et 
al., 2011). Although 16S rRNA gene was the first phylogenetic marker used to define Synechococcus lineages (Urbach et al., 1998; Fuller et al., 2003), some of these lineages cannot be discriminated by this marker, due to its too low taxonomic resolution. Therefore, several other markers such as the 16S-23S internal transcribed spacer region (ITS; Ahlgren and Rocap, 2012) or the single copy genes rpoCl (Toledo and Palenik, 1997), ntcA (Penno et al., 2006) and petB (Mazard et al., 2012) have been applied to study the genetic diversity of Synechococcus at higher resolution.

The western Pacific Ocean, an area extending from 15 to $55^{\circ} \mathrm{N}$, exhibits a wide variety of hydrographic conditions with surface water temperature ranging from $>29^{\circ} \mathrm{C}$ throughout the year in the tropical ocean to $<10{ }^{\circ} \mathrm{C}$ in the subarctic ocean, providing a comprehensive framework to study the effects of physico-chemical parameters on Synechococcus community structure. This area encompasses five marginal seas, including the South China Sea, the East China Sea, the Japan Sea, the Sea of Okhotsk and the Bering Sea, located along the northwestern boundary of the Pacific Ocean, and altogether covering the tropical, temperate and frigid zones (Fig. 1A). The warm current Kuroshio (Sawada and Handa, 1998) and the cold current Oyashio (Qiu, 2001) as well as their extension (the Northern Pacific current; Cummins and Freeland, 2007) also create some unique environments in the western Pacific Ocean. For example, the Tokara Strait where the Kuroshio Current flows out of the East China Sea to Pacific Ocean, has water temperature higher than the adjacent regions and does not exhibit strong seasonal variations (Nagata and Takeshita, 1985), whereas the western subtropical Pacific (East of Taiwan) is part of the western Pacific warm pool, a typical oligotrophic environment with low nutrient concentration. As some seasonal variations in the abundance of 
Synechococcus cells have been reported in the South China Sea (Xia et al., 2015a) and East China Sea (Guo et al., 2014), the present study mainly focused on late spring and summer (with the exception of Tokara Strait samples that were sampled in fall), in order to lower potential effects of seasonal variations on data interpretation. Besides covering a wide temperature and nutrient gradients, the study region also encompasses a large variety of optically distinct water bodies, from turbid coast to transparent open ocean waters. Therefore, this region likely comprises most of the niche types of Synechococcus that are reported so far in global ocean. Studying concomitantly the phylogenetic and pigment type composition of Synechococcus communities across such a wide range of environments allowed us to reveal the latitudinal distribution patterns of different clades and pigment types, to assess the relative importance of temperature and other environmental factors (in particular light quality) in determining niche partitioning of Synechococcus populations, and to unveil some of the strategies developed by Synechococcus to adapt to these different niches.

\section{Results}

\section{Synechococcus is widespread in surface waters of the northwestern Pacific Ocean}

Flow cytometry analyses showed that Synechococcus ubiquitously occurred in the surface waters (5-10 m depth) of northwestern Pacific Ocean (Fig. 1B). During the sampling periods, which are mainly late spring to summer, Synechococcus abundance was low in the subarctic waters (Sea of Okhotsk, Bering Sea and western subarctic Pacific Ocean; 0.7-6.7 $\times 10^{3}$ cells $\mathrm{mL}^{-1}$, average $1.7 \times 10^{3}$ cells $\left.\mathrm{mL}^{-1}\right)$ and South China Sea $\left(2.5 \times 10^{3}-3.9 \times 10^{4}\right.$ cells $\mathrm{mL}^{-1}$, average $7.1 \times 10^{3}$ cells $\left.\mathrm{mL}^{-1}\right)$, slightly higher in western subtropical Pacific Ocean $\left(2.5 \times 10^{3}\right.$ - 
$3.7 \times 10^{4}$ cells $\mathrm{mL}^{-1}$, average $1.2 \times 10^{4}$ cells $\left.\mathrm{mL}^{-1}\right)$, and the highest in the East China Sea $\left(8.0 \times 10^{3}-\right.$ $2.8 \times 10^{5}$ cells $\mathrm{mL}^{-1}$, average $7.1 \times 10^{4}$ cells $\left.\mathrm{mL}^{-1}\right)$ and Japan Sea $\left(1.9 \times 10^{3}-1.1 \times 10^{5}\right.$ cells $\mathrm{mL}^{-1}$, average $6.1 \times 10^{4}$ cells $\mathrm{mL}^{-1}$ ). In the Tokara Strait, a region located South of Japan that was sampled in November 2012, the abundance of Synechococcus was fairly low $\left(1.3-2.2 \times 10^{4}\right.$ cells $\mathrm{mL}^{-1}$; average $1.7 \times 10^{4}$ cells $\mathrm{mL}^{-1}$ ) but comparable with that in open ocean waters of the East China Sea collected in August 2009, suggesting that this was not due to seasonal variations (Fig. 1B). The abundances of Synechococcus were the most variable in the East China Sea, with the highest ones occurring in the northern part and in the mid-shelf region and the lowest ones in the estuary of Changjiang River. In the South China Sea, the abundance of Synechococcus was slightly higher in coastal than in open ocean waters. In the subarctic ocean, Synechococcus abundance was only around $5.0 \times 10^{2}$ cells $\mathrm{mL}^{-1}$ in the Bussol Strait connecting the Sea of Okhotsk and the Pacific Ocean, where a strong vertical mixing occurred. This was the lowest Synechococcus abundance recorded in all regions investigated in this study (Fig. 1B).

Altogether, the abundance of Synechococcus in surface water showed a weak positive correlation with temperature and a weak negative correlation with $\mathrm{PO}_{4}{ }^{3-}$ (Table S1). However, when looking at individual geographic regions, nutrients as well as temperature were often found to play a strong role in influencing the local abundance of Synechococcus. For example, cell density in the western subtropical Pacific Ocean was found strongly affected by $\mathrm{PO}_{4}{ }^{3-}$, whereas TIN, $\mathrm{PO}_{4}{ }^{3-}$, as well as temperature had a positive influence in the subarctic ocean. In the South China Sea, which displays a fairly low temperature with regard to the western subtropical Pacific Ocean, potentially due to the occurrence of a local coastal upwelling, we 
observed a weak negative relationship between temperature and Synechococcus abundance. In contrast, no significant correlation was observed between Synechococcus abundance and salinity, even in the East China Sea region that was influenced by local river input (Table S1).

\section{The different pigment types of Synechococcus colonize different niches in the environment}

The diversity of Synechococcus cpeBA operon in each community was estimated using the Shannon diversity index (Fig. S1). The Shannon diversity index of the 12 Synechococcus communities ranged from 0 to 2.18. WSAP-C5, which was collected from the western subarctic Pacific Ocean, had the lowest diversity, while TS-ST4, collected from the Tokara Strait, had the highest diversity. Altogether, the diversity of Synechococcus cpeBA operon was higher in tropical and subtropical waters than in temperate waters (Fig. S1).

Phylogenetic analysis of the $c p e B A$ operon sequences allowed us to separate four groups of pigment types (Fig. 2): 2, 3a, $3 \mathrm{dA}$ and the combination of $3 \mathrm{c}$ and $3 \mathrm{~dB}$, since the latter two types cannot be discriminated using this marker gene (Humily et al., 2014). It is worth noting that the only two strains known so far to exhibit a pigment type $3 \mathrm{~b}$ in culture (WH8103 and WH8109) are both genetically similar to $3 \mathrm{~dB}$ strains and possess a complete CA4-B island, but they have lost their ability for chromatic acclimation (Humily et al., 2013). Thus, pigment types $3 \mathrm{~b}$ and $3 \mathrm{~dB}$ also cannot be differentiated based on phylogenies using cpeBA (Humily et al., 2014). With these caveats in mind, our phylogenetic analyses showed that all pigment types detectable with this marker were present in the northwestern Pacific Ocean, but their relative abundance exhibited large geographical variations (Fig. 3). Synechococcus pigment type 2 was 
by far the least abundant, mainly occurring at ECS-KP01, a station influenced by a river plume.

210 Pigment type 3a was abundant in the Tokara strait and dominant in the whole East China Sea

region (Fig. 3). The group composed by type 3c and/or type $3 \mathrm{~dB}$ was largely dominant at both stations of the South China Sea as well as at the southernmost station of the Northern Pacific

Current. Most strikingly, chromatic acclimaters of the 3dA type constituted almost the sole pigment type detected in the western subarctic Pacific Ocean and Bering Sea, but occurred in mixture with $3 \mathrm{~dB} / 3 \mathrm{c}$ and $3 \mathrm{a}$ types at the northernmost station of Northern Pacific Current. ocean 
JS-JY1, and JS-SH2, which lie between latitudes $34^{\circ} \mathrm{N}$ and $40^{\circ} \mathrm{N}$ did not fall in any of these groups, indicating that the Synechococcus community compositions at those sites were unique and distinct from all other stations. Since all Japan Sea samples were collected in spring, we cannot exclude that their specificity results in part from seasonal variations. In the case of the Northern Pacific Current cruise, the two southernmost samples from the (NPC-K1 and A1), a region also sampled in spring, fell close to Tokara strait samples collected at the same latitude but in winter. Yet the latter set of samples fell within group B, which mainly gathers low latitude samples collected during summer, suggesting that latitude has a stronger effect on genetic diversity than season. To better split Synechococcus communities falling within group B (average similarity: 29.31\%), we did a further NMDS analysis specifically on this group (Fig. 4B). In the East China Sea, Synechococcus communities formed two major sub-groups composed of samples collected below and above $32^{\circ} \mathrm{N}$, respectively (Fig. 4B). Similar result was observed in the North Pacific Current (Fig. 4A). The coastal station ECS-KP01, which is strongly influenced by the river discharge, did not group together with other East China Sea samples.

More than $80 \%$ of reads in each sample were taxonomically assigned to known lineages using the reference database, except stations SCS-SEATS, SCS-LE09 and WSTP-ST1, where a higher number of unknown sequences were detected, potentially corresponding to novel clades (Fig. S3). All three Synechococcus subclusters were detected but S5.1 was by far the most abundant and widespread and constituted the only subcluster detected in the subarctic ocean (Fig. S3). S5.2 was only found in 13 samples, and its relative abundance was lower than $1 \%$ in 8 of them. The highest abundance of this subcluster $(15.5 \%)$ was detected at the coastal 
ECS-KP01 station. S5.3 was widespread but generally occurred at low abundance in the tropical and subtropical ocean and was virtually absent in cold waters of the Japan Sea, Sea of Okhotsk, western subarctic Pacific Ocean and Bering Sea. Yet, its abundance was fairly high in the Tokara Strait, especially at TS-ST5 (Figs. 5 and S3).

Altogether, 17 clades within S5.1 were detected in the western Pacific Ocean with clades I, II, III and VI being the most abundant (Fig. 5). Clade I mainly occurred in the subarctic ocean, while clade II widely dominated in tropical and subtropical areas. Compared to clade II, clade III also occurred in warm waters, but with a lower abundance and a narrower distribution (Figs. 5 and S3). Clade VI was also widely distributed in warm East China Sea (DH04 and HH12) and TS waters that are influenced by the Kuroshio Current. Clades VII and WPC2 exhibited a similar niche as S5.3, all displaying a wider distribution than clade VI. Clades Miyav and IX co-occurred with S5.2, mainly in waters influenced by a nutrient-rich and turbid river plume. WPC1 was mainly found in the East China Sea, with a similar distribution to clade III. Clade XV co-occurred with clade XVI and CRD1, especially in the Northern Pacific Current. RDA analysis showed that temperature, which explained $56.0 \%$ of the variance of Synechococcus community, was by far the most important factor determining the distribution of Synechococcus lineages in the northwestern Pacific Ocean (Fig. 6A). Clade I and IV relative abundances were associated both with low temperature and high nutrients, while all other clades showed reverse correlations with these parameters (Fig. 6A). This is consistent with the occurrence of these two clades being almost restricted to high latitudes $\left(>35^{\circ} \mathrm{N}\right)$, where the surface water temperature was lower than $12{ }^{\circ} \mathrm{C}$, while clade II often accounted for more than $60 \%$ of the sequences from $18^{\circ} \mathrm{N}$ to $34^{\circ} \mathrm{N}$ (Fig. 7A). Other important lineages, i.e. clades III, 
VI and S5.3, were only abundant between $25^{\circ} \mathrm{N}$ and $35^{\circ} \mathrm{N}$ (Fig. 7B).

Focusing on stations with temperature higher than $25{ }^{\circ} \mathrm{C}$ then allowed us to better discriminate the other important parameters driving the distribution of all lineages except clades I and IV (Fig. 6B). Clade IX, Env-Miyav and S5.2 were positively correlated to TIN and phosphate concentrations, consistent with their preference for river plume influenced waters (Figs. 6 and S3). Clades II and III also appeared to be well separated on correlation biplots (Fig. 6B). However, the parameters explaining their respective distribution remain unclear even though salinity could partially explain the observed differences, clade III being most abundant in the East China Sea (Fig. S4), which displayed the lowest salinity of the studied area (Table S2).

\section{Unveiling Synechococcus diversity within clade I in the western Pacific Ocean}

Although Synechococcus clade I is generally considered as typical of cold, mesotrophic and eutrophic waters (Zwirglmaier et al., 2008), members of this clade were also detected at low abundance in warm waters of East China Sea, TS and Northern Pacific Current (Fig. 8). Phylogenetic analysis of clade I rpoCl sequences showed that OTUs, which dominated in the subarctic ocean (Bering Sea, Sea of Okhotsk and western subarctic Pacific Ocean) clustered together. In contrast, OTUs occurring at lower latitude (East China Sea, Tokara Strait, Japan Sea and Northern Pacific Current) could be split into five additional subclades, displaying slightly different distribution patterns. Thus, one subclade is truly psychrophilic as it mainly dominated in subarctic oceanic waters, where the surface water temperature was lower than $12{ }^{\circ} \mathrm{C}$, while other subclades occur in warm waters with temperature ranging from 15 to $29{ }^{\circ} \mathrm{C}$. 
297

Fig. 8 also shows that the diversity of Synechococcus clade I was the highest between $34^{\circ} \mathrm{N}$ and $40^{\circ} \mathrm{N}$

\section{Linking Synechococcus genetic diversity and pigment content.}

In order to examine the links between Synechococcus phylogeny, as assessed using the rpoCl marker, and pigment content, as indirectly assessed using the cpeBA operon, a Spearman rank correlation analysis was performed over the whole Northwestern Pacific Ocean dataset (Fig. S5). It showed that pigment type 2 (no PUB) was strongly correlated with clades IX and Env-Miyav, while type 3a (low PUB:PEB) was associated with clades III, V and WPC1. Pigment type $3 \mathrm{dA}$ (one of the two types of chromatic acclimaters) was strongly positively correlated with clade I but anti-correlated with clade II. At last, the two indistinguishable pigment types $3 \mathrm{c}$ (high PUB:PEB) and $3 \mathrm{~dB}$ (the second chromatic acclimater type) were associated with clades II and UC-A. Thus, even if pigment types are not restricted to single clades, they seem to be preferentially found in certain clades in the field.

\section{Discussion}

\section{Factors controlling the abundance of Synechococcus in the northwestern Pacific Ocean}

This study, which analyzed surface samples collected from nine distinct cruises in the northwestern Pacific and its marginal seas, provides a comprehensive overview of the variability of Synechococcus abundance in this vast oceanic region and novel insights on how it relates with environmental factors. While the Synechococcus abundance was high in the 
subtropical and temperate areas $\left(25-40^{\circ} \mathrm{N}\right)$, especially near the coasts (East China Sea and Japan Sea), it was fairly low in the tropical (South China Sea) and subarctic regions (Figs.1B and 7A). Using a parametric regression model, a recent study also predicted strong variations of Synechococcus abundance with latitude, but when averaged over a year, the abundance peak was located around $45^{\circ} \mathrm{N}$ (Flombaum et al., 2013), i.e. at a significantly higher latitude than observed here (around $33.5^{\circ} \mathrm{N}$; Fig. 1B). This difference may arise in part from seasonal variations in Synechococcus abundance (see e.g. Fig. S5 in Flombaum et al., 2013) but also from the fact that latitudinal variations of abundance could significantly differ between the marginal seas studied here and the central part of the northwestern Pacific Ocean, and this local distribution pattern may have been missed by the global model developed by Flombaum and coworkers. Indeed, the highest cell densities reported here were all recorded in coastal seas (Fig. 1B), with a maximal abundance of $2.8 \times 10^{5}$ Synechococcus cells $\mathrm{mL}^{-1}$ in the East China Sea in summer. This value is one order of magnitude higher than those reported during summer 1998 in the same area (Jiao et al., 2005), but is comparable to those reported in other nutrientrich areas around the world, such as the Bedford Basin $(\mathrm{Li}, 1998)$ and the Martha Vineyard's coastal observatory in summertime (Hunter-Cevera et al., 2015), as well as the Arabian Sea (Liu et al., 1998) or areas influenced by local upwelling (Partensky et al., 1996). It is however much lower than those observed in the Costa Rica dome, where record abundances between $1.2 \times 10^{6}$ and $3.7 \times 10^{6}$ cells $\mathrm{mL}^{-1}$ have been reported (Saito et al., 2005).

A number of previous studies have suggested that the net abundance of Synechococcus is mainly controlled by temperature and nutrients (Agawin et al., 2000; Zwirglmaier et al., 2008; Tai and Palenik, 2009). Here we found that when considering our whole dataset on 
surface waters of the western North Pacific Ocean, Synechococcus abundance was only weakly correlated with temperature and phosphate availability and not correlated with TIN availability (Table S1). Yet, this overall trend clearly masks local disparities. As for the first parameter, temperature seems to be more influential to Synechococcus abundance in low temperature subarctic ocean than tropical/subtropical warm waters. This is in agreement with a previous study showing that Synechococcus abundance is positively correlated to temperature only below $14{ }^{\circ} \mathrm{C}(\mathrm{Li}, 1998)$. Although Flombaum and coworkers predicted that the abundance of Synechococcus cells in the world ocean will increase by $14 \%$ at the end of this century, due to the global rise in sea surface temperature (Flombaum et al., 2013), they also foresaw that this increase will not equally affect all latitudes. Our results indeed suggest that in the northwestern Pacific Ocean, effects of global change should be much more significant in the subarctic region, where both surface temperature and Synechococcus abundance are low, than in temperate, tropical or subtropical waters.

As concerns nutrient concentrations, our statistical analyses showed that Synechococcus abundance was positively influenced by nutrient availability in the subarctic ocean but not in the tropical/subtropical waters (Table S1). Synechococcus abundance in the latter regions was higher in coastal and river plumes influenced waters than in oligotrophic oceanic waters and low salinity estuarine waters (Fig. 1B). This is in agreement with the dome-shaped distribution proposed by Liu et al., (1998), which suggested that Synechococcus grow best in waters with intermediate level of nitrate. Consistently, Chung and coworkers, who also studied the distribution of Synechococcus in the East China Sea observed during non-flooding summer the occurrence of a bloom of PE-rich Synechococcus on the outer boundaries of the Changjiang 
River in water with a salinity comprised between 31 and 32 ppt (Chung et al., 2014).

\section{Niche partitioning of marine Synechococcus pigment types}

The wide diversity of pigment types that we observed in the northwestern Pacific Ocean translates the large variety of light environments encountered in this vast oceanic region, from turbid estuaries to transparent open ocean waters (Fig. 3). Interestingly, while different Synechococcus pigment types co-occurred within most samples, one phenotype generally predominated. This observation supports the hypothesis that the spectral properties of seawater exert a strong selective pressure on Synechococcus populations, favoring the pigment type possessing phycobilisomes with light absorption characteristics matching at best the local spectrum of photosynthetically available radiation (PAR). While low PUB:PEB cells (type 3a) dominated the population all over the East China Sea, Synechococcus cells lacking PUB (type 2) were only abundant in a low transparency station (St. ECS-KP01, see Fig. 2 of Chung et al., 2014). This indicates that the latter pigment type is well adapted to harvest light in these fairly turbid waters (Olson et al., 1988; Wood et al., 1998), where the PAR spectrum is likely shifted towards yellow/yellow-green light due to organic matter in suspension (Kirk, 1994), while pigment type 3a can stand wider PAR spectra, extending from blue-green to yellow-green (see e.g., Six et al., 2007 for representative absorption spectra of pigment types 2 and 3). It is noteworthy that although analysis of the cpeBA operon diversity does not allow to detect Synechococcus type 1 cells since they lack phycoerythrin, this pigment type was probably also present at station ECS-KP01, as these phycocyanin-rich Synechococcus were recently shown to predominate in the highly turbid diluted waters of the Changjiang River (Chung et al., 2014). 
As mentioned above, type $3 \mathrm{~dB}$ cells, (i.e. chromatic acclimaters possessing a CA4-B genomic island; Humily et al., 2013), are not distinguishable from type 3c (i.e. cells with a fixed high PUB:PEB ratio) based on analyses of the cpeBA operon. It is therefore not possible from our data to precisely assess the respective habitat of these two pigment types, though it appears that both are absent from turbid, coastal as well as high latitude waters. Previous studies using flow cytometry or spectrofluorometry have concluded that blue, oligotrophic areas are populated with type 3c cells (Olson et al., 1988; Campbell and Iturriaga, 1988; Lantoine and Neveux, 1997; Wood et al., 1999; Haverkamp et al., 2009; Everroad and Wood, 2012). Yet, it is worth noting that these methods also cannot distinguish between type $3 \mathrm{c}$ and $3 \mathrm{~dB}$ cells, since both these pigment types exhibit high PUB:PEB ratios in blue light (Humily et al., 2013). In contrast, our study clearly indicated, for the first time, that type $3 \mathrm{dA}$, i.e. chromatic acclimaters possessing a CA4-A genomic island, were by far the predominant pigment type in the subarctic ocean area. Due to the low angle of the sun at these latitudes, light intensity decreases rapidly with depth, resulting in an unstable light environment (Nosaka et al., 2014). Thus, the ability to perform chromatic acclimation seemingly constitutes an advantage in environments with variable light conditions, consistent with a previous study showing the abundance of chromatic acclimaters in permanently mixed waters of the English Channel (Humily et al., 2014).

\section{Niche partitioning of Synechococcus clades}

Synechococcus clades are known to partition more strongly along the horizontal scale than with depth (Zwirglmaier et al., 2008; Choi and Noh, 2009; Sohm et al., 2015), indicating that even though our study dealt only with populations from surface waters, the relative 
abundance of clades that we observed at any given station is truly representative of the diversity of local Synechococcus populations. Several studies have suggested that clades I through IV are the most abundant clades at the global scale, with clades I and IV predominantly found in cold and temperate waters, while clades II and III prefer warmer waters (Zwirglmaier et al., 2008; Mella-Flores et al., 2011; Post et al., 2011; Huang et al., 2012). Here we show that clade I was by far the dominant clade in the subarctic ocean and temperate waters of Japan Sea and Northern Pacific Current, whereas clade II appears to be its counterpart in subtropical and tropical areas (Figs. 5 and S4), suggesting that these two dominant clades are mutually exclusive. In contrast, clade IV was scarce over all the studied area, including cold waters, in agreement with a previous report of low abundances of the latter clade in the Bering Sea (Huang et al., 2012).

Interestingly, a number of clade I sequences was also retrieved from East China Sea, Tokara Strait and Northern Pacific Current (Fig. 8), consistent with previous studies reporting the occurrence of this clade as a minor component of Synechococcus communities in tropical and subtropical, warm waters (Fuller et al., 2006; Ahlgren et al., 2014). This wide distribution of clade I might be due in part to the large microdiversity existing within this clade. A single subclade encompassing eight OTUs (subclade I-F) dominated in the subarctic ocean cluster, while OTUs present in warm and temperate waters (East China Sea, Tokara Strait and Northern Pacific Current) appeared more diverse, clustering into 5 separate subclades (I-A through I-E; Fig. 8). Interestingly, members of all six subclades co-occurred at intermediate latitudes (Japan Sea and/or Northern Pacific Current), suggesting that the realized niches of warm- and coldadapted clade I populations overlap in this transition area in which genetic exchange could 
occur, e.g., by lateral gene transfer. The wider abundance and geographic distribution of clade I compared to clade IV could also possibly be explained by the fact that members of the former clade are genetically more versatile than members of the latter clade, as suggested by comparative genome analysis of strains representative of these two clades (Dufresne et al., 2008; Scanlan et al., 2009; Tai and Palenik, 2009)

Although clade III was locally abundant in warm waters $\left(>25{ }^{\circ} \mathrm{C}\right)$, it had a more limited distribution pattern than clade II and was only abundant in the nutrient-rich and/or low salinity waters of East China Sea (Figs. 5 and S4). This observation is in sharp contrast with the realized niche of this clade in the eastern basin of the Mediterranean Sea, a very oligotrophic, strongly phosphate-depleted, high-salinity area, where clade III constitutes the locally dominant Synechococcus taxon (Mella-Flores et al., 2011; Farrant et al., 2016). This suggests that, like clade I, clade III encompasses several subpopulations with very distinct nutrient and/or salinity preferenda, i.e. distinct ecotypes.

The fourth most abundant taxon in the northwestern Pacific was clade VI but its geographical distribution was limited to the Tokara strait and the central part of East China Sea (Figs. 5 and S4), suggesting that it has a narrow niche. Yet, correlation analyses did not allow us to clearly identify factors delineating its niche, and its overall distribution is also not well understood so far since counts of this clade have often been merged with those of the related clades V, VII and/or CRD1 (Zwirglmaier et al., 2008; Huang et al., 2012). Thus, more field and culture studies are clearly needed to characterize this group. A few other clades within S5.1 as well as members of S5.3 were also frequently encountered in northwestern Pacific Ocean warm waters but generally at lower relative abundances (Fig. 5). Clade WPC1, which was first 
reported in the East China Sea and Japan Sea (Choi and Noh 2009), may co-occur with clade III, whereas Synechococcus clades VII and S5.3 occur in waters with variable nutrients and light supply (Fuller et al., 2006; Post et al., 2011). Although previous studies suggested that clades XV and XVI have a global distribution (Ahlgren and Rocap, 2006; Sudek et al., 2015), we rather suggest that these two clades mainly occur between $30^{\circ}$ and $35^{\circ} \mathrm{N} / \mathrm{S}$ (Ahlgren and Rocap, 2006; Huang et al., 2012; Sudek et al., 2015) and in upwelling regions (Sohm et al., 2015), i.e. in areas characterized by nutrient-rich and intermediate environmental conditions. At last, members of clades IX and Miyav as well as S5.2 showed similar niches, with an abundance peak in the river plume influenced waters (Fig. 5). These taxa were previously found to be abundant in the Hong Kong estuarine waters (Xia et al., 2015b), suggesting that they have a high nutrient requirement and are possibly halotolerant, as it is the case for S5.2 (Chen et al., 2006; Dufresne et al., 2008).

\section{The combination of genetic and pigment diversity contributes to Synechococcus ubiquity}

Our phylogenetic tree based on $c p e B A$ operon sequences clearly grouped together members of several distinct phylogenetic clades (Fig. 2). This is consistent with several comparative phylogenetic analyses based on the one hand on phycobilisome rod genes and on the other hand on housekeeping genes (ITS, ribosomal proteins, etc.) or allophycocyanin genes that have suggested that the variety of pigment types that occurs among lineages of S5.1 results from multiple lateral transfers of PE-encoding genes between Synechococcus lineages during the evolution of this genus (Six et al., 2007; Haverkamp et al., 2008; Haverkamp et al., 2009).

Another study has also evoked a specific loss of mpeBA genes in pigment type 2 strains as an 
alternative hypothesis (Everroad and Wood, 2012). Whatever the origin of this discrepancy between Synechococcus clades and pigment types, it remains possible to assign with some confidence a pigment type to a specific clade in the field, whenever there is a concomitant dominance at one location of both one pigment type and one clade over all others. For instance, clade I populations from the subarctic North Pacific Ocean are clearly almost exclusively of type $3 \mathrm{dA}$. This is consistent with the fact that all clade I strains able to chromatically acclimate sequenced so far possess a CA4-A island (Humily et al., 2013). Similarly, the comparison of Figures 3 and 5 suggest that most cells at St. ECS-KP01 seemingly belong to clade Miyav and have phycobilisomes of type 3a, while those at St. SCS-LE04 predominantly belong to clade II and possess phycobilisomes of type 3c and/or 3dB (Figs. S5 and S6).

It also appears that members of Synechococcus communities belonging to a single clade can possess phycobilisomes of different types, consistent with observations on isolates (Fig. 2, but see also Six et al., 2007; Haverkamp et al., 2008; Haverkamp et al., 2009; Everroad and Wood 2012). For instance, although the Synechococcus community at St. ECS-KP13 was largely dominated by clade II (Fig. 5), there were several co-occurring pigment types at this station: 3a, 3c and/or 3dB (Fig. 3). It is noteworthy though that the low proportion of pigment type $3 \mathrm{dA}$ sequences also found at this station is likely attributable to minor clades, possibly WPC2 or UC-A (Fig. 5), since all clade II and III strains able to chromatically acclimate sequenced thus far are of pigment type $3 \mathrm{~dB}$, that is possess a CA4-B island (Humily et al., 2013).

In conclusion, although combining genetic and pigment diversity analyses has rarely been applied to field populations prior to this study, this approach clearly brings interesting new 
perspectives on the extent of the flexibility of the Synechococcus genus as a whole with regard to environmental parameters. The highly variable phycobiliprotein composition and chromophore content of Synechococcus antenna complexes, and hence particularly wide PAR range in which cells of this genus can thrive, clearly confers this group a flexibility with regard to light quality that is unique among marine phytoplankters. Yet, the adaptive capacity of Synechococcus is not limited to the spectral properties of seawater, but also concerns other key parameters, including temperature, salinity and nutrient availability, for which adaptive specific traits have been selected by billions years of evolution (Dufresne et al., 2008; Scanlan et al., 2009; Pittera et al., 2014). Altogether this adaptability explains the extraordinary ubiquity of Synechococcus not only in the northwestern Pacific Ocean but more generally in the marine environment. Our study provides some unprecedented general patterns of Synechococcus abundance, pigment diversity and clade composition in a key oceanic region, the northwestern Pacific Ocean. Despite the fact that most samples were collected during summer, we cannot rule out that some of the observed variability actually arises from temporal changes, since seasonal variations of Synechococcus abundance and community composition have been reported in some regions of the western Pacific Ocean (Xia et al. 2015a) and elsewhere (Tai and Palenik 2009). Thus, future studies are required to better decipher the effects of seasonality on picocyanobacterial abundance and community composition over a wider part of the study area but also to highlight potential effects of large multi-year oceanographic events, such as El Niño.

\section{Experimental Procedures}




\section{Sample collection}

8

Samples were collected from surface waters (5-10 m depth) of the western Pacific Ocean and its marginal seas in a total of nine cruises (Table S2, Fig. 1A). With the exception of the cruise in the Tokara Strait, which was conducted in November, all other cruises were performed in late spring to summer. Water was collected using Niskin bottles (12 L) attached to a conductivity, temperature, and depth (CTD) rosette multi-sampler (Sea Bird Electronics, USA). At each station, $0.5-3 \mathrm{~L}$ of seawater was pre-filtered through a $3.0 \mu \mathrm{m}(47 \mathrm{~mm})$ polycarbonate membrane (PALL Corporation) and then filtered onto a $0.22 \mu \mathrm{m}(47 \mathrm{~mm})$ polycarbonate membrane for DNA extraction. Membranes were frozen at $-80{ }^{\circ} \mathrm{C}$ immediately after filtration. Temperature and salinity of seawater were measured using a conductivity-temperature-depth rosette system (CTD, Sea Bird Electronics). Seawater $(1.8 \mathrm{~mL})$ for flow cytometry analysis was fixed with $0.5 \%$ (final concentration) seawater-buffered paraformaldehyde. All samples were frozen in $-80{ }^{\circ} \mathrm{C}$ until analysis. Inorganic nutrients including $\mathrm{NO}_{3}{ }^{-}+\mathrm{NO}_{2}{ }^{-}$(limit of

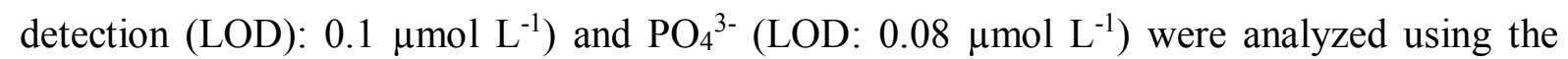
Technicon AA3 Auto-Analyzer (Bran+Luebbe, Germany) onboard or a QuAAtro AutoAnalyzer (Bran+Luebbe, Germany) on shore. Seawater samples for nutrient analysis were filtered through $0.45 \mu \mathrm{m}$ acetate fiber membranes, except for the cruises in the Bering Sea, Tokara Strait and Sea of Okhotsk, for which samples were not prefiltered before measurements.

\section{Analysis of Synechococcus abundance}

Synechococcus cells were enumerated using a Becton-Dickinson FACSCalibur flow cytometer equipped with dual lasers of $488 \mathrm{~nm}$ and $635 \mathrm{~nm}$ with high flow rate (Liu et al., 
2014). Ten microliters of yellow-green fluorescent beads ( $1 \mu \mathrm{m}$, Polysciences, Warrington, PA, USA) were added to each sample as an internal standard. Flow cytometric data were analyzed using WinMDI software 2.9 (Joseph Trotter, Scripps Research Institute, La Jolla, CA, USA). All Synechococcus abundance data were used to generate a contour plot (Fig. 1B) using the contouring and shading of the Weighted-average gridding algorithm in Ocean Data View (Schlitzer, 2009). X and Y scale-lengths were set as 10 per- $\mathrm{km}$. The relationship between the abundance of Synechococcus and environmental factors (Spearman's rank correlation coefficient) was analyzed by using SPSS (IBM SPSS Statistics Inc., Chicago). Data with total

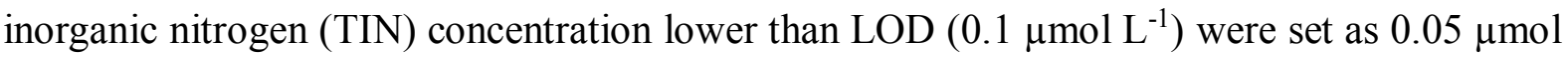
$\mathrm{L}^{-1}$ and with $\mathrm{PO}_{4}{ }^{3-}$ concentration lower than $\operatorname{LOD}\left(0.08 \mu \mathrm{mol} \mathrm{L} \mathrm{L}^{-1}\right)$ were set as $0.04 \mu \mathrm{mol} \mathrm{L} \mathrm{L}^{-1}$.

\section{Clone library construction and sequencing of cpeBA operon}

DNA was extracted using the enzyme/phenol-chloroform protocol described elsewhere (Riemann et al., 2000). Primer sets SynB3FW (5'-TCAAGGAGACCTACATCG-3') and SynA1R (5'-CAGTAGTTGATCAGRCGCAGGT-3') were used to amplify the cpeBA operon sequences (Everroad and Wood 2006). PCR reaction was carried out in $50 \mu \mathrm{L}$ master mix including $5 \mu \mathrm{L}$ of $10 \times$ buffer, $2 \mu \mathrm{L}$ of $\mathrm{MgCl}_{2}(25 \mathrm{mM}), 4 \mu \mathrm{L}$ of dNTPs $(2.5 \mathrm{mM}), 0.2 \mu \mathrm{l}$ of Platinum Taq DNA polymerase (5 U, Invitrogen, USA), $1 \mu \mathrm{L}$ of each primer $(10 \mu \mathrm{M}), 1 \mu \mathrm{L}$ of DNA template (around $20 \mathrm{ng} / \mu \mathrm{L}$ ) and $35.8 \mu \mathrm{L}$ water. PCR products were purified using a PureLinkTM Quick Gel Extraction Kit (Invitrogen, USA). Purified DNA sequences were cloned into the PCR4.0 vector by using a TOPO TA cloning kit (Invitrogen, USA). In total, twelve clone libraries were constructed (Table S3). Forty to sixty positive clones from each 
library were purified with a PureLink quick plasmid miniprep kit (Invitrogen, USA) and sequenced in the MingBo sequencing company (Shanghai, China).

\section{Phylogenetic and diversity analysis of cpeBA operon}

All cpeBA operon sequences were aligned using DNAman (Woffelman, 2004) and trimmed to equal length (506 bp). Chimeras were checked and removed using Mothur (Schloss et al., 2009; Edgar et al., 2011). The operational taxonomic units (OTUs) numbers were calculated at the cut-off level of $95 \%$ nucleotide identity. The representative sequence of each OTU was randomly extracted and then identified by using BLAST searches against the National Center for Biotechnology Information (NCBI) database (http://www.ncbi.nlm.nih.gov). OTUs for which no significant similarity (E-value $>10)$ was found in NCBI database and heterotrophic bacteria sequences were removed. Abundance of left OTUs was used to calculate Shannon index using Primer 5 (Primer-E-Ltd, UK). The Shannon diversity index was calculated as follows: $\mathrm{H}=-\sum \mathrm{Pi} \mathrm{In} \mathrm{Pi}$, where $\mathrm{Pi}=\mathrm{S} / \mathrm{N}, \mathrm{S}=$ number of sequences of one OTU, $\mathrm{N}=$ total number of sequences in the sample (Shannon, 2001).

Representative OTU sequences were used for phylogenetic analyses. Maximum Likelihood phylogenetic tree was constructed with MEGA 6 (Kumar et al., 1994) using the K2+G+I model for nucleotide evolution with 200 bootstraps. The most similar reference sequences were retrieved from the NCBI database. The sequences were aligned using ClustalW according to codon structure (Higgins et al., 1994). Strain pigment information was derived from published literature (Everroad and Wood, 2012; Humily et al., 2013; Humily et al., 2014) and from the Roscoff Culture Collection (http://roscoff-culture- 
collection.org/strains/shortlists/taxonomic-groups/marine-synechococcus).

\section{PCR and 454 sequencing}

Amplification of the $r p o C l$ gene sequences was performed as previously described (Mühling et al., 2006). The first round of PCR used the primer rpoCl-N5 and the C-terminal primer $r p o C l-C$, and the PCR products were used as templates for a second round of PCR with primer rpoCl-39F (5'-adaptor A+barcode+GGNATNGTNTGYGAGCGYTG) and rpoCl462R (5'-adaptor B+CGYAGRCFCTTGRTCAGCTT (Mühling et al., 2006; Xia et al., 2015b). PCR products were gel-purified using the Qiaquick gel purification kit, as described by the manufacturer (Qiagen, Germany). Library quantification was done by fluorometry using the Quant-iT picoGreen dsDNA Assay Kit (Invitrogen, USA). Amplicons were mixed in equal amounts and sequenced in a two-region 454 run on a GS PicoTiterPlate using a GS Junior pyrosequencing system according to manufacturer instructions (Roche, 454 Life Sciences, Branford, CT, USA). The number of sequences obtained from each sample is listed in Table S3.

\section{Post-run Sequence analysis}

Analysis of rpoCl sequences was conducted using the microbial ecology community software program Mothur (Schloss et al., 2009). Raw sequences were processed by removing barcodes and primers only reads with an average quality score above 20 and read lengths between $300 \mathrm{nt}$ and $500 \mathrm{nt}$ were taken into account. Sequence denoise was carried out using the command shhh.seqs with sigma value of 0.01 . Chimeras were analyzed using the command 
chimera.uchime and removed. After the above quality control, sequences were identified by local Blast using BioEdit (Hall 1999) with an expectation value 1.0E-100. Reference sequences of each lineage are listed in Table S4. Sequences displaying less than $80 \%$ identity to the reference sequences or classified as Prochlorococcus and Synechocystis were removed. We then subsampled 1,739 reads from each sample for calculating DNA distance. A "shared" file was generated using Mothur's make.shared routine. OTU numbers were calculated at the cutoff level of $95 \%$ nucleotide identity. The Shannon diversity index was calculated as explained above, then after removing OTUs containing only one sequence, the Bray-Curtis similarity between samples was also computed. The Bray-Curtis similarity matrix was used to carry out NMDS analysis using Primer 5 (Primer-E-Ltd, UK).

In order to calculate the relative abundance of each phylogenetic lineage of Synechococcus, the representative sequence of each OTU was randomly extracted using command get.oturep and then identified by local Blast using Bio-Edit (Hall, 1999). The phylotype of each reference sequence is listed in Table S4. Since the similarity of sequences within each lineage ranged from $90 \%$ to $100 \%$ (Table S5), sequences displaying less than $90 \%$ identical to the reference sequences were assigned as unclassified (Xia et al., 2015b). The relative abundance of each lineage was calculated and used to generate a heatmap using HemI (Deng et al., 2014), then square root transformed in order to perform average linkage clustering using Pearson correlation matrices. Clade I rpoCl sequences were aligned according to codon structure and a Maximum Likelihood (ML) phylogenetic tree was constructed using MEGA 6 (Kumar et al., 1994) with a K2P+G model. A heatmap showing the relative abundance of each OTU was generated using iTol (Letunic and Bork, 2007). 


\section{Redundancy and correlation analysis}

The relationship between measured environmental parameters (Table S7) and Synechococcus community composition was studied by redundancy analysis (RDA) using not included. Data with total inorganic nitrogen (TIN) concentration lower than LOD $(0.1 \mu \mathrm{mol}$

$\left.\mathrm{L}^{-1}\right)$ were set as $0.05 \mu \mathrm{mol} \mathrm{L}{ }^{-1}$ and with $\mathrm{PO}_{4}{ }^{3-}$ concentration lower than LOD $\left(0.08 \mu \mathrm{mol} \mathrm{L}^{-1}\right)$ were set as $0.04 \mu \mathrm{mol} \mathrm{L} \mathrm{L}^{-1}$. The matrix was generated using the relative abundance of each lineage transformed by square root. Environmental data were normalized using $\mathrm{z}$-score transformation. The significance of the eigenvalues and species-environment correlations of the first three axes were determined by Monte Carlo tests (500 permutations).

The spearman correlation between pigment types and phylogenetic lineages was analyzed using the corrplot R-package (Wei, 2011). S5.2 and clade VIII which are known to mainly consist of type 1 Synechococcus (Fuller et al., 2003; Dufresne et al., 2008) were not included in the analysis.

\section{Sequences submission}


666

667

668

669

670

671

\section{Acknowledgements:}

We thank the captain and crew of the R/V Dongfanghong 2 (China), R/V Hakuho Maru (Japan), R/V Tansei Maru (Japan), and R/V Professor Multanovskiy (Russia) for offering opportunity for sampling during the cruises. We thank Dr. Dong Han Choi for providing pigment information of Synechococcus sp. strain KORDI-100 and Dr. Hisashi Endo providing nutrient data of Bearing Sea cruise. We also thank Candy Li for measuring Synechococcus cell abundance in Japan Sea, Eric for collecting DNA samples from Japan Sea and Wang Guo for sequencing ropCl gene sequences from samples collected from Tokara Strait.

This study was supported by the National Basic Research Program (“973” Program) of China through grant no. 2009CB421203 and the Research Grants Council of Hong Kong RGF grants (661912 and 661813) provided to H. Liu. F. Partensky and L. Garczarek were funded by the French "Agence Nationale de la Recherche" program BioAdapt SAMOSA (ANR-13ADAP-0010). Also this work was partly supported by the Grant-in-Aid for \#22221001, \#22681004, and the project "The study of Kuroshio ecosystem dynamics for sustainable management” from MEXT, Japan.

4

6

67

8

69

0 
Conflict of interest: The authors declare that there is no conflict of interest.

676

677

678

679

680

681

682

683

684

685

686

687

\section{References}

Agawin, N.S., Duarte, C.M., Agusti, S. (2000) Nutrient and temperature control of the contribution of picoplankton to phytoplankton biomass and production. Oceanogr 45: $591-600$

Ahlgren, N.A., Rocap, G. (2006) Culture isolation and culture-independent clone libraries reveal new marine Synechococcus ecotypes with distinctive light and N physiologies. Appl Environ Microbiol 72: 7193-7204.

Ahlgren, N.A., Rocap, G. (2012) Diversity and distribution of marine Synechococcus: multiple gene phylogenies for consensus classification and development of qPCR assays for sensitive measurement of clades in the ocean. Front Microbiol 3: 213.

Ahlgren, N.A., Noble, A., Patton, A.P., Roache-Johnson, K., Jackson, L., Robinson, D. et al., (2014) The unique trace metal and mixed layer conditions of the Costa Rica upwelling dome support a distinct and dense community of Synechococcus. Limnol Oceanogr 59: 2166-2184.

Buitenhuis, E.T., Li, W.K., Vaulot, D., Lomas, M.W., Landry, M., Partensky, F., et al., (2012) Picophytoplankton biomass distribution in the global ocean. Earth Syst Sci Data 4: 37-46.

Campbell, L., and Iturriaga, R. (1988) Identification of Synechococcus spp. in the Sargasso Sea by immunofluorescence and fluorescence excitation spectroscopy performed on individual cells. Limnol Oceanogr 33: 1196-1201.

Chen, B., Liu, H., Landry, M.R., Dai, M., Huang, B., Sune, J. (2009) Close coupling between phytoplankton growth and microzooplankton grazing in the western South China Sea. Limnol Oceanogr 54: 1084-1097.

Chen, F., Wang, K., Kan, J., Suzuki, M.T., Wommack, K.E. (2006) Diverse and unique picocyanobacteria in Chesapeake Bay, revealed by 16S-23S rRNA internal transcribed spacer sequences. Appl Environ Microbiol 72: 2239-2243.

Choi, D.H., Noh, J.H. (2009) Phylogenetic diversity of Synechococcus strains isolated from the East China Sea and the East Sea. FEMS Microbiol Ecol 69: 439-448. 
Chung, C-C., Huang, C-Y., Gong, G-C., Lin, Y-C. (2014) Influence of the Changjiang River flood on Synechococcus ecology in the surface waters of the East China Sea. Microb Ecol 67: $273-285$.

Chung, C-C., Gong, G-C., Huang, C-Y., Lin, J-Y., Lin, Y-C. (2015) Changes in the Synechococcus assemblage composition at the surface of the east China Sea due to flooding of the Changjiang river. Microb Ecol: 1-12.

Cummins, P.F., and Freeland, H.J. (2007) Variability of the North Pacific Current and its bifurcation. Prog Oceanogr 75: 253-265.

Deng, W., Wang, Y., Liu, Z., Cheng, H., Xue, Y. (2014) Hemi: A toolkit for illustrating heatmaps. PloS One 9: e111988.

Dufresne, A, Ostrowski, M., Scanlan, D.J., Garczarek, L., Mazard, S., Palenik, B.P. et al., (2008) Unraveling the genomic mosaic of a ubiquitous genus of marine cyanobacteria. Genome Biol 9: R90.

Edgar, R.C., Haas, B.J., Clemente, J.C., Quince, C., Knight, R. (2011) UCHIME improves sensitivity and speed of chimera detection. Bioinformatics 27: 2194-2200.

Everroad, C., Michelle, W.A. (2006) Comparative molecular evolution of newly discovered picocyanobacterial strains reveals a phylogenetically informative variable region of $\beta$ phycoerythrin. J Phycol 42: 1300-1311.

Everroad, C., Six, C., Partensky, F., Thomas, J-C., Holtzendorff, J., Wood, A.M. (2006) Biochemical bases of type IV chromatic adaptation in marine Synechococcus spp. $J$ Bacteriol 188: 3345-3356.

Everroad, C., Wood, A.M. (2012) Phycoerythrin evolution and diversification of spectral phenotype in marine Synechococcus and related picocyanobacteria. Mol Phylogenet Evol 64: $381-392$.

Farrant G.K., Doré H., Cornejo-Castillo F.M., Partensky F., Ratin M., Ostrowski M. et al. (2016). Delineating ecologically significant taxonomic units from global patterns of marine picocyanobacteria. Proc Natl Acad Sci USA 113; E3365-E3374.

Flombaum, P., Gallegos, J.L., Gordillo, R.A., Rincón, J., Zabala, L.L., Jiao, N., et al., (2013) Present and future global distributions of the marine Cyanobacteria Prochlorococcus and Synechococcus. Proceed Natl Acad Sci USA 110: 9824-9829. 
Fuller, N.J., Marie, D., Partensky, F., Vaulot, D., Post, A.F., Scanlan, D.J. (2003) Clade-specific $16 \mathrm{~S}$ ribosomal DNA oligonucleotides reveal the predominance of a single marine Synechococcus clade throughout a stratified water column in the Red Sea. Appl Environ Microbiol 69: 2430-2443.

Fuller, N.J., Tarran, G.A., Yallop, M., Orcutt, K.M., Scanlan, D.J. (2006) Molecular analysis of picocyanobacterial community structure along an Arabian Sea transect reveals distinct spatial separation of lineages. Limnol Oceanogr 51: 2515-2526.

Garcia-Pichel, F., Belnap, J., Neuer, S., Schanz, F. (2003) Estimates of global cyanobacterial biomass and its distribution. Algolog Stud 109: 213-227.

Gascuel, O. (1997) BIONJ: an improved version of the NJ algorithm based on a simple model of sequence data. Mol Biol Evol 14: 685-695.

Guo, C., Liu, H., Zheng, L., Song, S., Chen, B., and Huang, B. (2014) Seasonal and spatial patterns of picophytoplankton growth, grazing and distribution in the East China Sea. Biogeosciences 11: 1847-1862.

Hall, T.A. (1999) BioEdit: a user-friendly biological sequence alignment editor and analysis program for Windows 95/98/NT. Nucl Acids Symp Ser 41: 95-98.

Haverkamp, T., Acinas, S.G., Doeleman, M., Stomp, M., Huisman, J., Stal, L.J. (2008) Diversity and phylogeny of Baltic Sea picocyanobacteria inferred from their ITS and phycobiliprotein operons. Environ Microbiol 10: 174-188.

Haverkamp, T.H., Schouten, D., Doeleman, M., Wollenzien, U., Huisman, J., Stal, L.J. (2009) Colorful microdiversity of Synechococcus strains. (picocyanobacteria) isolated from the Baltic Sea. ISME J 3: 397-408.

Higgins, D., Thompson, J., Gibson, T., Thompson, J.D., Higgins, D.G,, Gibson, T.J. (1994) CLUSTAL W: improving the sensitivity of progressive multiple sequence alignment through sequence weighting, position-specific gap penalties and weight matrix choice. Nucleic Acids Res 22:4673-4680.

Huang, S., Wilhelm, S.W., Harvey, H.R., Taylor, K., Jiao, N., Chen, F. (2012) Novel lineages of Prochlorococcus and Synechococcus in the global oceans. ISME J 6: 285-297.

Humily, F., Partensky, F., Six, C., Farrant, G.K., Ratin, M., Marie, D., et al., (2013) A gene island with two possible configurations is involved in chromatic acclimation in marine 
Synechococcus. PloS One 8: e84459.

Humily, F., Farrant, G.K., Marie, D., Partensky, F., Mazard, S., Perennou, M., et al., (2014) Development of a targeted metagenomic approach to study a genomic region involved in light harvesting in marine Synechococcus. FEMS Microbiol Ecol 88: 231-249.

Hunter-Cevera, K.R., Post, A.F., Peacock, E.E., Sosik, H.M. (2015) Diversity of Synechococcus at the Martha's Vineyard coastal observatory: Insights from culture isolations, clone libraries, and flow cytometry. Microb Ecol: 1-14.

Jiao, N., Yang, Y., Hong, N., Ma, Y., Harada, S., Koshikawa, H., et al., (2005) Dynamics of autotrophic picoplankton and heterotrophic bacteria in the East China Sea. Cont Shelf Res 25: $1265-1279$.

Kirk. J.T. (1994) Light and photosynthesis in aquatic ecosystems. Cambridge university press. $509 \mathrm{pp}$.

Kumar, S., Tamura, K., Nei, M. (1994) MEGA: molecular evolutionary genetics analysis software for microcomputers. Computer applications in the biosciences: CABIOS 10: 189-191.

Lantoine, F., Neveux, J. (1997) Spatial and seasonal variations in abundance and spectral characteristics of phycoerythrins in the tropical northeastern Atlantic Ocean. Deep Sea Res Pt I 44: 223-246.

Larsson, J., Celepli, N., Ininbergs, K., Dupont, C.L., Yooseph, S., Bergman, B., et al., (2014) Picocyanobacteria containing a novel pigment gene cluster dominate the brackish water Baltic Sea. ISME J 8: 1892-1903.

Letunic, I., Bork, P. (2007) Interactive Tree Of Life (iTOL): an online tool for phylogenetic tree display and annotation. Bioinformatics 23: 127-128.

Li, Q., Legendre, L., Jiao, N. (2015) Phytoplankton responses to nitrogen and iron limitation in the tropical and subtropical Pacific Ocean. J Plankt Res 37: 306-319.

Li, WK. (1998) Annual average abundance of heterotrophic bacteria and Synechococcus in surface ocean waters. Limnol Oceanogr 43: 1746-1753.

Liu, H., Campbell, L., Landry, M., Nolla, H., Brown, S., Constantinou, J. (1998) Prochlorococcus and Synechococcus growth rates and contributions to production in the Arabian Sea during the 1995 Southwest and Northeast Monsoons. Deep Sea Res Pt II 45: 
Liu, H., Jing, H., Wong, T.H., Chen, B. (2014) Co-occurrence of phycocyanin-and phycoerythrin-rich Synechococcus in subtropical estuarine and coastal waters of Hong Kong. Environ Microbiol Rep 6: 90-99.

Mazard, S., Ostrowski, M., Partensky, F., Scanlan, D.J. (2012) Multi-locus sequence analysis, taxonomic resolution and biogeography of marine Synechococcus. Environ Microbiol 14: $372-386$.

Mella-Flores, D., Mazard, S., Humily, F., Partensky, F., Mahé, F., Bariat, L., et al., (2011) Is the distribution of Prochlorococcus and Synechococcus ecotypes in the Mediterranean Sea affected by global warming? Biogeosciences 8: 2785-2804.

Mühling, M., Fuller, N.J., Somerfield, P.J., Post, A.F., Wilson, W.H., Scanlan, D.J., et al., (2006) High resolution genetic diversity studies of marine Synechococcus isolates using rpoC1-based restriction fragment length polymorphism. Aquat Microb Ecol 45: 263-275.

Nagata, Y., Takeshita, K. (1985) Variation of the sea surface temperature distribution across the Kuroshio in the Tokara Strait. J Oceanogr Soc Japan 41: 244-258.

Nosaka, Y., Isada, T., Kudo, I., Saito, H., Hattori, H., Tsuda, A., et al., (2014) Light utilization efficiency of phytoplankton in the Western Subarctic Gyre of the North Pacific during summer. J oceanogr 70: 91-103.

Olson, R., Chisholm, S., Zettler, E., Armbrust, E. (1988) Analysis of Synechococcus pigment types in the sea using single and dual beam flow cytometry. Deep Sea Research 35: 425440.

Ong, L., and Glazer, A. (1991) Phycoerythrins of marine unicellular cyanobacteria. I. Bilin types and locations and energy transfer pathways in Synechococcus spp. phycoerythrins. J Biol Chem 266: 9515-9527.

Partensky, F., Blanchot, J., Lantoine, F., Neveux, J., Marie, D. (1996) Vertical structure of picophytoplankton at different trophic sites of the tropical northeastern Atlantic Ocean. Deep Sea Res Pt I 43: 1191-1213.

Partensky, F., Blanchot, J., Vaulot, D. (1999) Differential distribution and ecology of Prochlorococcus and Synechococcus in oceanic waters: a review. Bull Inst Oceanogr Monaco 19: 457-476. 
Penno, S., Lindell, D., Post, A.F. (2006) Diversity of Synechococcus and Prochlorococcus populations determined from DNA sequences of the N-regulatory gene ntcA. Environ microbiol 8: 1200-1211.

Pittera, J., Humily, F., Thorel, M., Grulois, D., Garczarek, L., Six, C. (2014) Connecting thermal physiology and latitudinal niche partitioning in marine Synechococcus. ISME J 8: $1221-1236$.

Post, A.F., Penno, S., Zandbank, K., Paytan, A., Huse, S.M., Welch, D.M. (2011) Long term seasonal dynamics of Synechococcus population structure in the Gulf of Aqaba, Northern Red Sea. Front Microbiol 2: 131.

Qiu, B. (2001) Kuroshio and Oyashio currents: Academic Press.

Riemann, L., Steward, G.F., Azam, F. (2000) Dynamics of bacterial community composition and activity during a mesocosm diatom bloom. Applied and Environ Microbiol 66: 578587.

Saito, M.A., Rocap, G., Moffett, J.W. (2005) Production of cobalt binding ligands in a Synechococcus feature at the Costa Rica upwelling dome. Limnol Oceanogr 50: 279-290.

Sawada, K., and Handa, N. (1998) Variability of the path of the Kuroshio ocean current over the past 25,000 years. Nature 392: 592-595.

Scanlan, D.J., Ostrowski, M., Mazard, S., Dufresne, A., Garczarek, L., Hess, W.R., et al., (2009) Ecological genomics of marine picocyanobacteria. Microbiol Mol Biol Rev 73:

SchlipAt;29.(2009) Ocean data view. Available at https://odv.awi.de/

Schloss, P.D., Westcott, S.L., Ryabin, T., Hall, J.R., Hartmann, M., Hollister, E.B., et al., (2009) Introducing mothur: open-source, platform-independent, community-supported software for describing and comparing microbial communities. Appl Environ Microbiol 75: 75377541.

Shannon, C.E. (2001) A mathematical theory of communication. ACM SIGMOBILE Mob Comput Commun Rev 5: 3-55.

Six, C., Thomas, J.C., Garczarek, L., Ostrowski, M., Dufresne, A., Blot, N., et al., (2007) Diversity and evolution of phycobilisomes in marine Synechococcus spp.: a comparative genomics study. Genome Biol 8: R259.

Sohm, J.A., Ahlgren, N.A., Thomson, Z.J., Williams, C., Moffett, J.W., Saito, M.A., et al., 
(2015) Co-occurring Synechococcus ecotypes occupy four major oceanic regimes defined by temperature, macronutrients and iron. ISME J 10: 333-345.

Stomp, M., Huisman, J., de Jongh, F., Veraart, A.J., Gerla, D., Rijkeboer, M., et al., (2004) Adaptive divergence in pigment composition promotes phytoplankton biodiversity. Nature 432: 104-107.

Stomp, M., Huisman, J., Vörös, L., Pick, F.R., Laamanen, M., Haverkamp, T., et al., (2007) Colourful coexistence of red and green picocyanobacteria in lakes and seas. Ecol Lett 10: 290-298.

Sudek, S., Everroad, R.C., Gehman, ALM., Smith, J.M., Poirier, C.L., Chavez, F.P., et al., (2015) Cyanobacterial distributions along a physico-chemical gradient in the Northeastern Pacific Ocean. Environ Microbiol 17: 3692-3707.

Tai, V., Palenik, B. (2009) Temporal variation of Synechococcus clades at a coastal Pacific Ocean monitoring site. ISME J 3: 903-915.

Toledo, G., Palenik, B. (1997) Synechococcus diversity in the California current as seen by RNA polymerase (rpoC1) gene sequences of isolated strains. Appl Environ Microbiol 63: 4298-4303.

Urbach, E., Scanlan, D.J., Distel, D.L., Waterbury, J.B., and Chisholm, S.W. (1998) Rapid diversification of marine picophytoplankton with dissimilar light-harvesting structures inferred from sequences of Prochlorococcus and Synechococcus (Cyanobacteria). J Mol Evol 46: 188-201.

Wang, K., Wommack, K.E., Chen, F. (2011) Abundance and distribution of Synechococcus spp. and cyanophages in the Chesapeake Bay. Appl and environ microbio 77: 7459-7468.

Wei T. (2011). Corrplot: visualization of a correlation matrix. $\mathrm{R}$ package version 0.77 . https://CRAN.R-project.org/package=corrplot.

Woffelman, C. (2004) DNAMAN for Windows, Version 5.2. 10. Lynon Biosoft, Institute of Molecular Plant Sciences, Netherlands: Leiden University.

Wood, A.M. (1985) Adaptation of photosynthetic apparatus of marine ultraphytoplankton to natural light fields. Nature 316: 253-255.

Wood, A.M., Phinney, D.A., and Yentsch, C.S. (1998) Water column transparency and the distribution of spectrally distinct forms of phycoerythrin-containing organisms. Mar Ecol 
903

904

905

906

907

908

909

910

911

912

Wood, A.M., Lipsen, M., and Coble, P. (1999) Fluorescence-based characterization of phycoerythrin-containing cyanobacterial communities in the Arabian Sea during the Northeast and early Southwest Monsoon (1994-1995). Deep Sea Res Pt II 46: 1769-1790.

Xia, X., Guo, W., and Liu, H. (2015a) Dynamics of the bacterial and archaeal communities in the Northern South China Sea revealed by 454 pyrosequencing of the $16 \mathrm{~S}$ rRNA gene. Deep Sea Res Pt II 117: 97-107.

Xia, X., Vidyarathna, N.K., Palenik, B., Lee, P., Liu H. (2015b) Comparison of the seasonal variation of Synechococcus assemblage structure in estuarine waters and coastal waters of Hong Kong. Appl Environ Microbiol 81: 7644-7655.

Zwirglmaier, K., Jardillier, L., Ostrowski, M., Mazard, S., Garczarek, L., Vaulot, D., et al., (2008) Global phylogeography of marine Synechococcus and Prochlorococcus reveals a distinct partitioning of lineages among oceanic biomes. Environ Microbiol 10: 147-161.

18

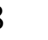

(1)

(1)

(1)

3

04

05

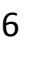


Fig. 1 Localization of studied sites in the northwestern Pacific Ocean. A, Samples used for

915

916

917

918 pyrosequencing of the $r p o C l$ gene are shown as dots and those used for constructing cpeBA operon clone libraries as circles. Samples from different cruises were labeled in different colors. B, Contour plot (created with Ocean Data View (Schlitzer, 2009)) showing Synechococcus cell concentrations in the northwestern Pacific Ocean using Weighted-average gridding over all sampling stations. Black dots indicate sampling stations. South China Sea (SCS); East China Sea (ECS); western subtropical Pacific Ocean (WSTP); Tokara Strait (TS); Japan Sea/East Sea (JS); Northern Pacific Current (NPC); Sea of Okhotsk (OKH); western subarctic Pacific Ocean (WSAP); Bering Sea (BS); subarctic ocean (SA) including BS, OKH and WSAP.

Fig. 2 Maximum-likelihood phylogenetic tree of cpeBA operon sequences of Synechococcus obtained from the western Pacific Ocean. Representative sequences of 95\% OTUs containing more than 2 sequences were included in the dataset. Right bars show three clades formed by cpeBA operon sequences obtained from the western Pacific Ocean. Strain pigment information derived from Everroad et al., (2012) and Humily et al., (2014). Bootstrap values greater than $50 \%$ were shown on nodes of branches. Clade names for reference strains are given after strain names.

Fig. 3 Distribution of Synechococcus pigment types in surface waters of the northwestern Pacific Ocean, as indirectly assessed using the diversity of the cpeBA operon (see Fig. 2). Pigment type assignment was made following the nomenclature proposed by Humily et al., (2014).

Fig. 4 NMDS plots showing the similarity of Synechococcus communities based on rpoCl gene. Samples from different cruises were labeled in different colors. A, similarity of Synechococcus communities in the western Pacific Ocean. B, similarity of Synechococcus community in the tropic/subtropics oceans of the western Pacific Ocean.

Fig. 5 Heatmap displaying the relative abundances of Synechococcus lineages for any given station of the northwestern Pacific Ocean, as assigned based on rpoCl gene. Data were 
944 transformed by square root transformation. Unclassified sequences were not included.

945

946 Fig. 6 Correlation biplots based on a redundancy analysis (RDA) depicting the relationship 947 between the environmental factors and Synechococcus lineages. A. All samples with 948 environmental data were analyzed. B. Samples with temperature higher than $25{ }^{\circ} \mathrm{C}$ were 949 analyzed. Relative abundance of each lineage was normalized by square root-transformation.

950 The environmental data were $\mathrm{z}$-score transformed. $* \mathrm{P}<0.05, * * \mathrm{P}<0.01$.

952 Fig. 7 Relative abundance of the different lineages versus latitude. A, Relative abundance of 953 the two dominant clades (I and II). B, Relative abundance of all other major lineages.

954

955 Fig. 8 Maximum-likelihood phylogenetic tree of clade I Synechococcus using the 100 most 956 abundant rpoCl OTUs across all samples. Heatmap on right-hand side shows the relative 957 abundance of OTUs in each library (square root transformed). Only nodes with bootstrap 958 values higher than $50 \%$ are shown. Letters A-F on right-hand side correspond to different 959 subclades within clade I. 

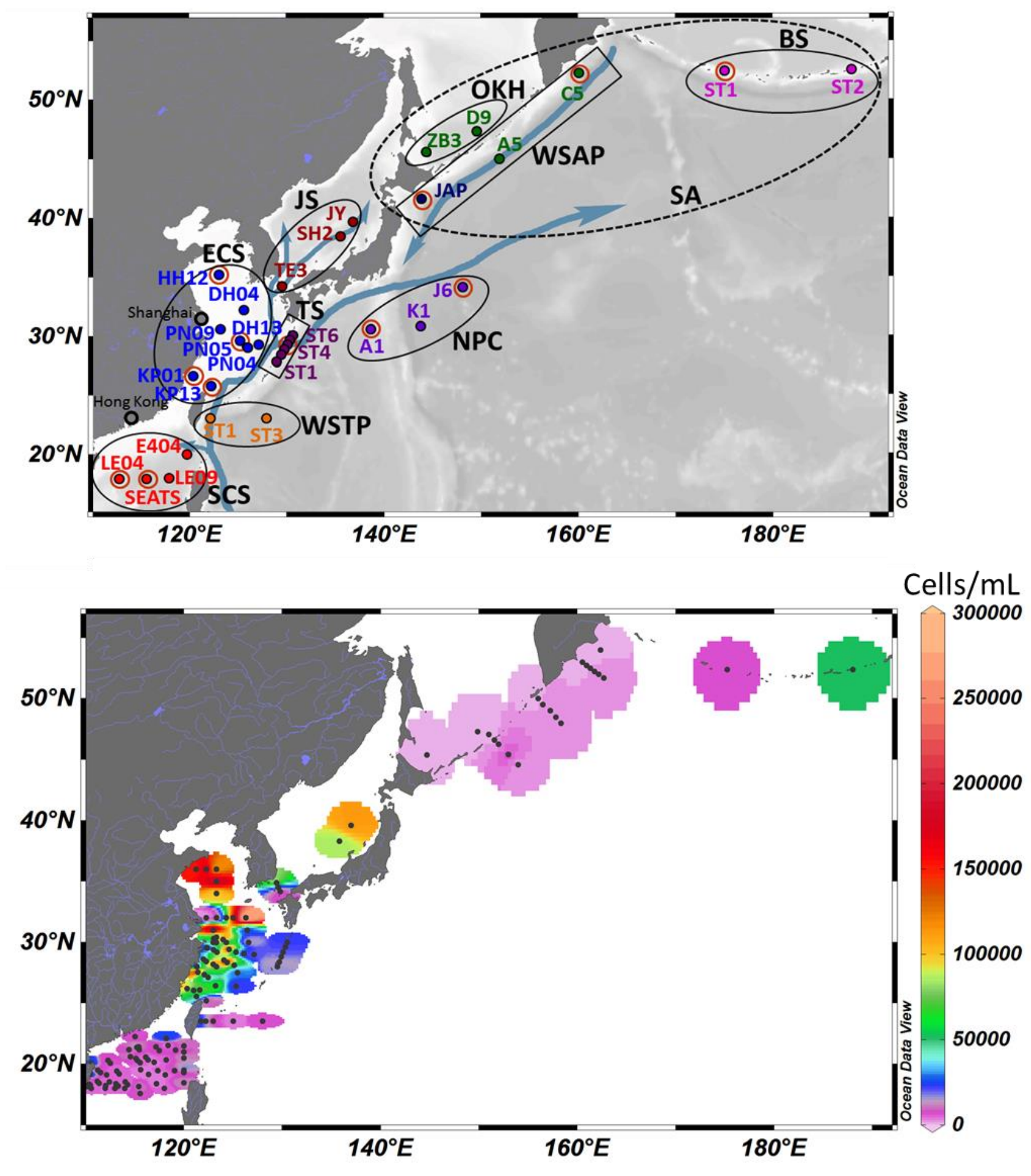

Xia et al. Fig. 1 


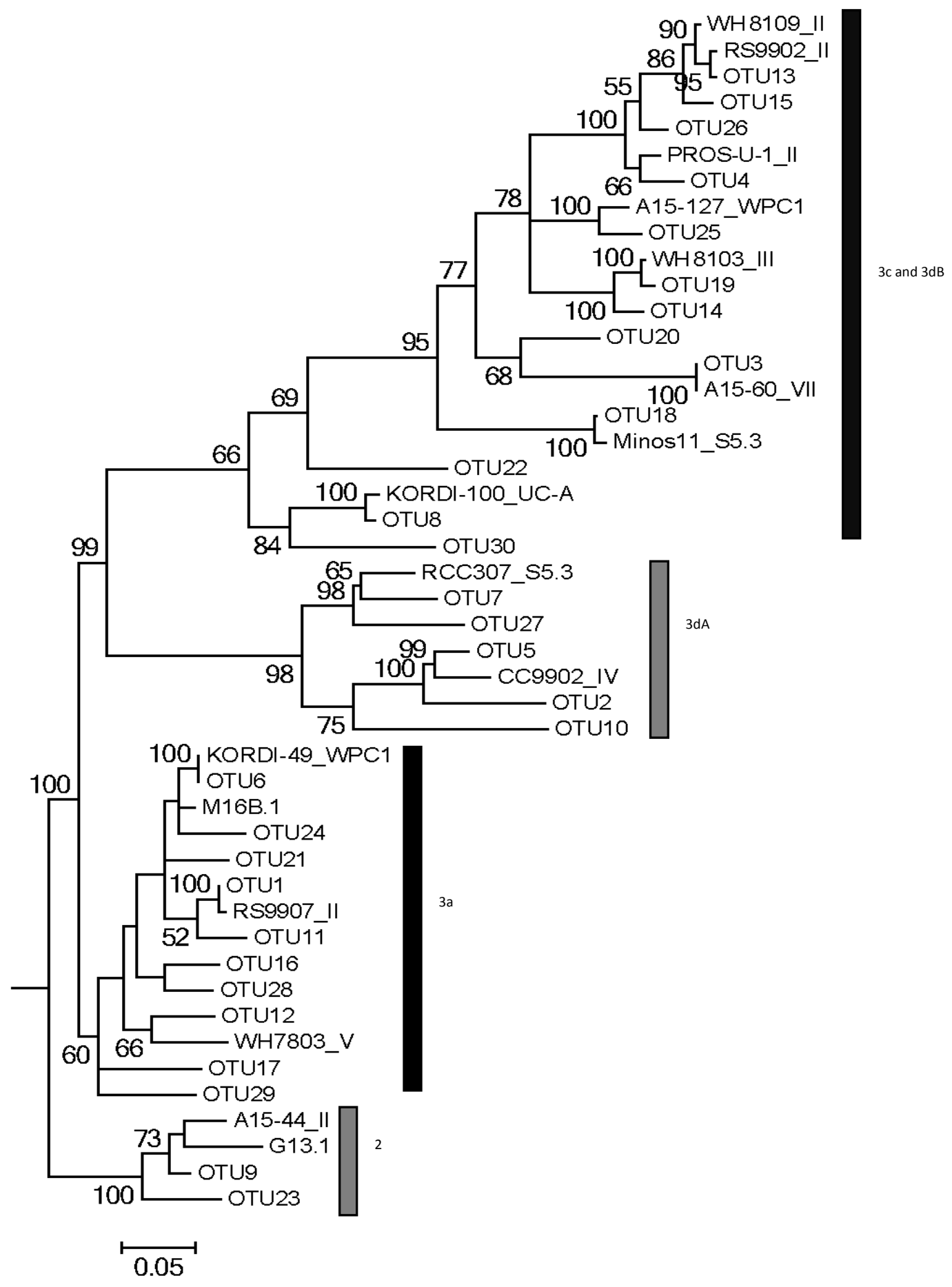

Xia et al. Fig. 2 


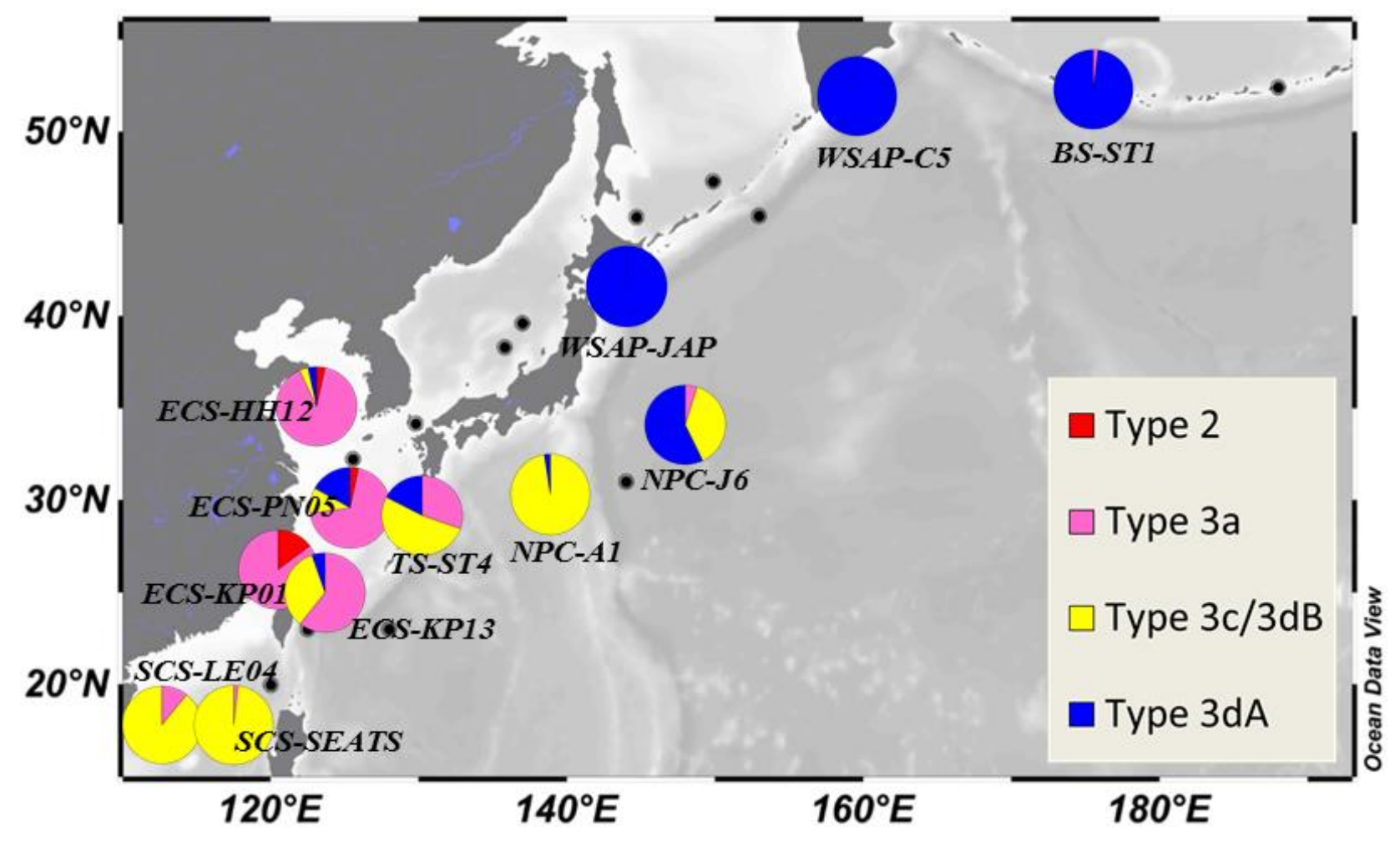

Xia et al. Fig. 3 


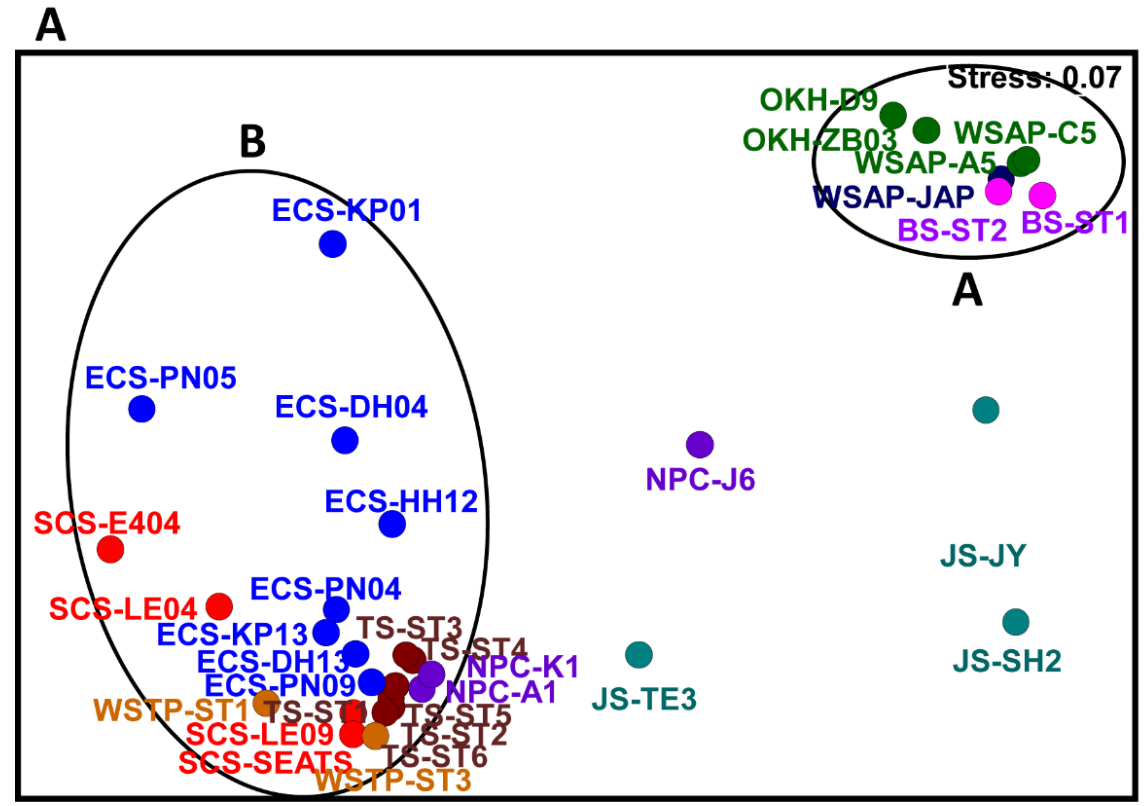

B

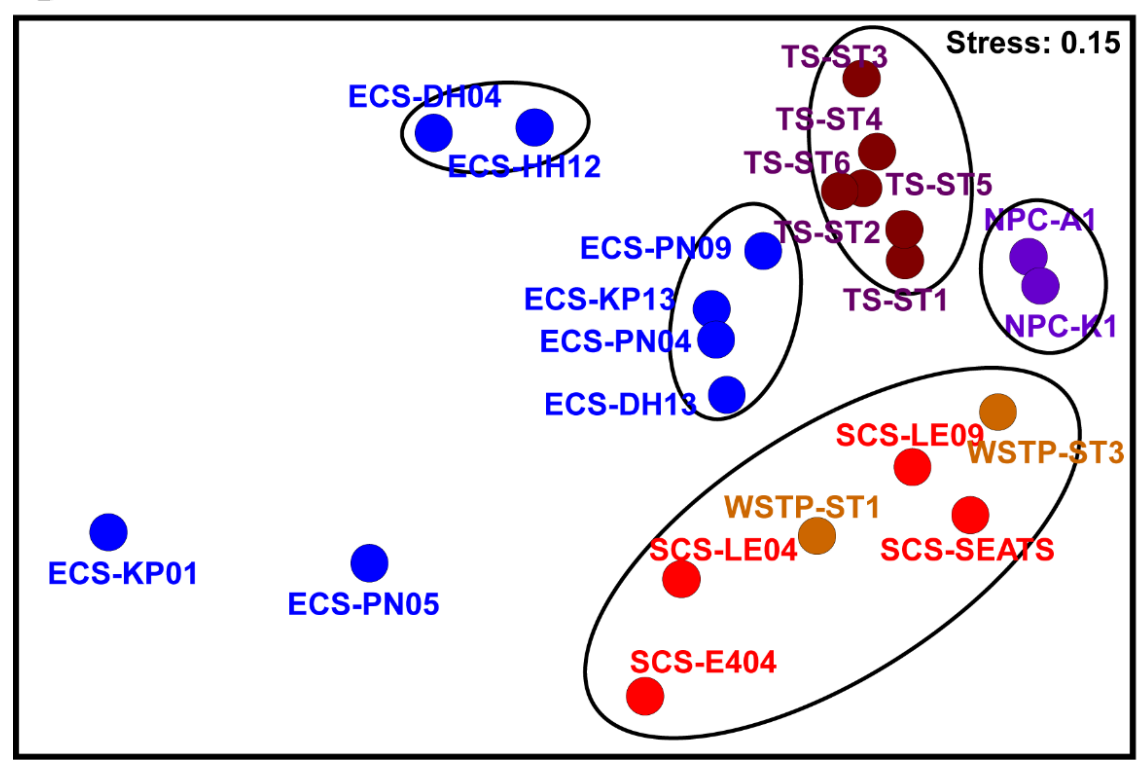

Xia et al. Fig. 4

\section{Cruise}

- scs:

South China Sea

- ECS:

East China Sea

WSTP:

Western Subtropical Pacific

TS:

Tokara Strait

- NPC:

Northern Pacific Current

JS:

Japan Sea

WSAP:

Western Subarctic Pacific

OKH:

Sea of Okhotsk

BS:

\section{Bering Sea}




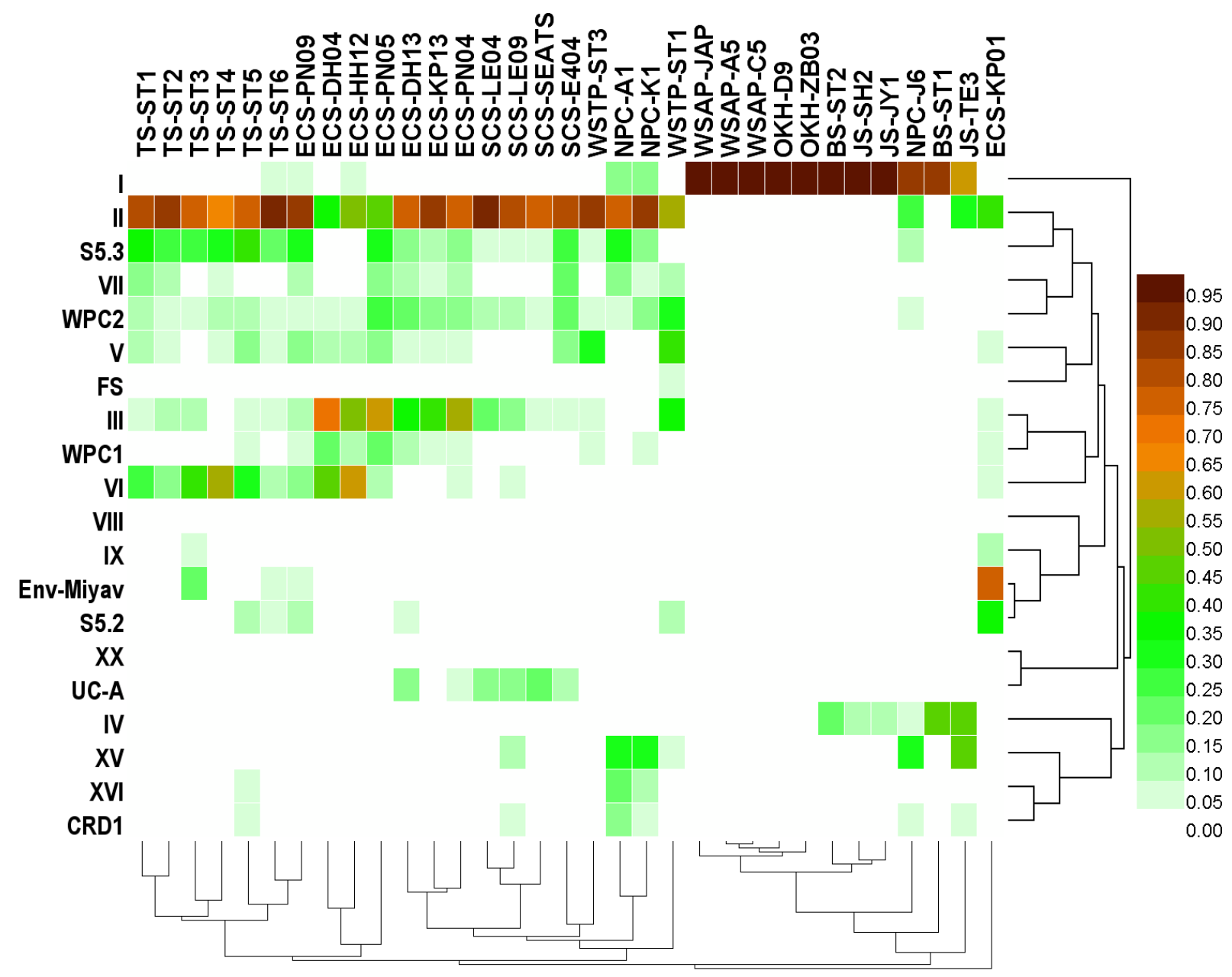

Xia et al. Fig. 5 


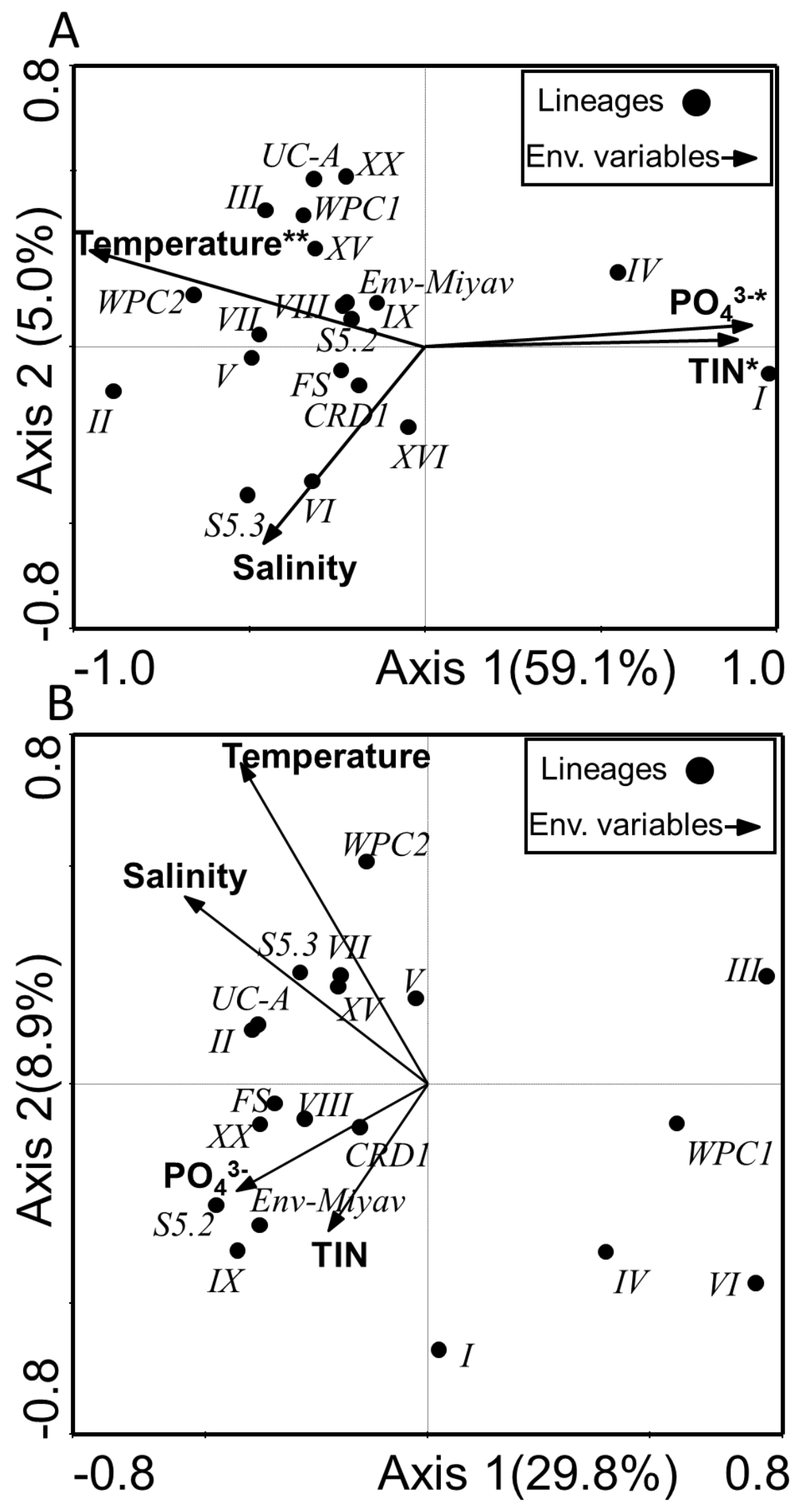

Xia et al. Fig. 6 

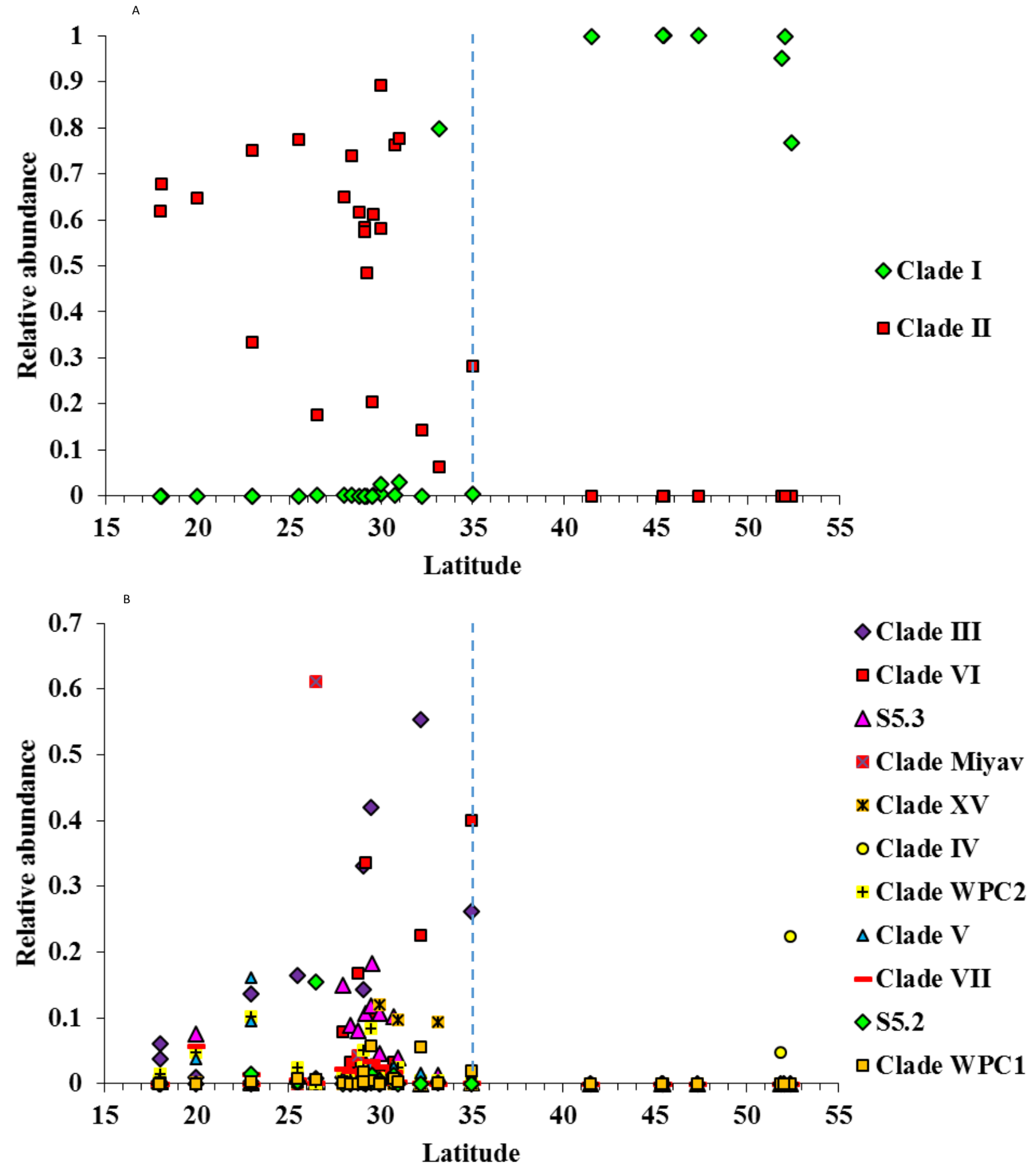

Xia et al. Fig. 7 


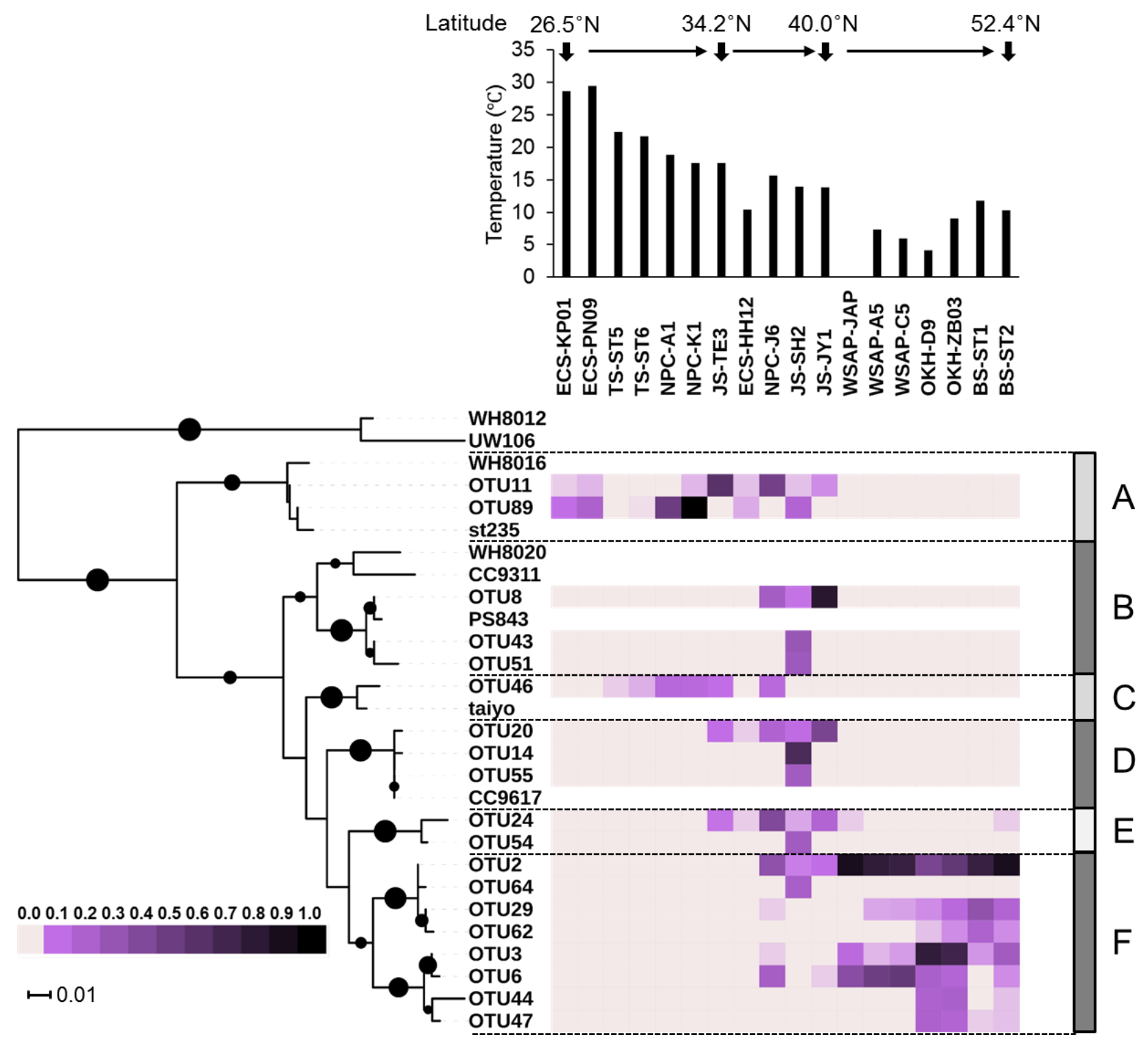

Xia et al. Fig. 8 